\title{
Insect Epigenetic Mechanisms Facing Anthropogenic-Derived Contamination, an Overview
}

\author{
Gabriela Olivares-Castro ${ }^{1, *}$, Lizethly Cáceres-Jensen ${ }^{2}$ (I) , Carlos Guerrero-Bosagna ${ }^{3,4}$ and Cristian Villagra ${ }^{1}$ (I) \\ 1 Instituto de Entomología, Universidad Metropolitana de Ciencias de la Educación, Avenida José \\ Pedro Alessandri 774, Santiago 7760197, Chile; cristian.villagra@umce.cl \\ 2 Laboratorio de Físicoquímica Analítica, Departamento de Química, Facultad de Ciencias Básicas, \\ Universidad Metropolitana de Ciencias de la Educación, Santiago 7760197, Chile; lyzethly.caceres@umce.cl \\ 3 Department of Physics, Chemistry and Biology (IFM), Linköping University, 58183 Linköping, Sweden; \\ carlos.guerrero.bosagna@liu.se \\ 4 Environmental Toxicology Program, Department of Integrative Biology, Uppsala University, \\ 75236 Uppsala, Sweden \\ * Correspondence: gp.olivares.castro@gmail.com
}

Citation: Olivares-Castro, G.;

Cáceres-Jensen, L.; Guerrero-Bosagna,

C.; Villagra, C. Insect Epigenetic

Mechanisms Facing Anthropogenic-

Derived Contamination, an Overview.

Insects 2021, 12, 780. https://

doi.org/10.3390/insects12090780

Academic Editors: Frédérique

Peronnet and Jean-Michel Gibert

Received: 21 July 2021

Accepted: 19 August 2021

Published: 31 August 2021

Publisher's Note: MDPI stays neutral with regard to jurisdictional claims in published maps and institutional affiliations.

Copyright: (c) 2021 by the authors. Licensee MDPI, Basel, Switzerland. This article is an open access article distributed under the terms and conditions of the Creative Commons Attribution (CC BY) license (https:// creativecommons.org/licenses/by/ $4.0 /)$.
Simple Summary: Epigenetic molecular mechanisms (EMMs) are capable of regulating and stabilizing a wide range of living cell processes without altering its DNA sequence. EMMs can be triggered by environmental inputs. In insects, EMMs contribute to explaining both negative effects as well as adaptive responses towards environmental cues. Among these stimuli are chemical stressors, such as pesticides. We review the link between EMMs and pesticides in insects. We suggest that pesticide chemical behavior promotes both lethal and sublethal exposure of both target and non-target insects. As a consequence, for several native and beneficial insect (e.g., pollinators), EMMs are involved in diseases and disruptive responses due to pesticides, while in the case of pest species, EMMs are linked in the development of pesticide resistance and hormesis. We discuss the consequences of these in the context of insect global decline and biotic homogenization.

Abstract: Currently, the human species has been recognized as the primary species responsible for Earth's biodiversity decline. Contamination by different chemical compounds, such as pesticides, is among the main causes of population decreases and species extinction. Insects are key for ecosystem maintenance; unfortunately, their populations are being drastically affected by human-derived disturbances. Pesticides, applied in agricultural and urban environments, are capable of polluting soil and water sources, reaching non-target organisms (native and introduced). Pesticides alter insect's development, physiology, and inheritance. Recently, a link between pesticide effects on insects and their epigenetic molecular mechanisms (EMMs) has been demonstrated. EMMs are capable of regulating gene expression without modifying genetic sequences, resulting in the expression of different stress responses as well as compensatory mechanisms. In this work, we review the main anthropogenic contaminants capable of affecting insect biology and of triggering EMMs. EMMs are involved in the development of several diseases in native insects affected by pesticides (e.g., anomalous teratogenic reactions). Additionally, EMMs also may allow for the survival of some species (mainly pests) under contamination-derived habitats; this may lead to biodiversity decline and further biotic homogenization. We illustrate these patterns by reviewing the effect of neonicotinoid insecticides, insect EMMs, and their ecological consequences.

Keywords: imidacloprid; insectageddon; hormetic responses; sublethal exposure

\section{Introduction}

Epigenetics is a complex field of research concerning the molecular mechanisms capable of modifying DNA expression through organism' ontogeny. These changes can even become inheritable [1]. Epigenetic alterations can take place through an ever-expanding set 
of chemical modifications, known as epigenetic molecular mechanisms (EMMs), including changes affecting nucleotides such as DNA methylation (i.e., C5-cytosine methylation), post-translational modifications of histone variants, and nucleosome configuration, as well as noncoding RNA effects on living cells, among others [1-3] (Table 1). Epigenetic changes can take place stochastically, although EMMs are often the result of the influence of environmental cues on organisms [4]. Epigenetics has gained increasing interest among basic and applied scientists, originating a mounting body of interdisciplinary research and providing us with novel approaches to longstanding questions in biological sciences $[1,5,6]$. Several insect species have contributed as model organisms to the study of EMMs. These processes have been found to contribute in the regulation and stabilization of the basic self-organizing functions of insect life. Among these are the response of insects towards different environmental cues and disturbances, including those derived from human activities. Therefore, EMMs participate in the insect expression of varied responses to environmental stimuli such as polymorphisms and social caste specialization [7-9], insecticide resistance [10,11], and a myriad of other aspects of insect biology in model systems and wild species [12,13]. Unfortunately, while in recent decades we have been able to enrich current explanations of EMMs thanks to the study of varied aspects of insect life in several species, at the same time, their populations have been experiencing steady declines [14-16].

Table 1. Currently described mechanisms of stable epigenetic inheritance *.

\begin{tabular}{|c|c|c|}
\hline $\begin{array}{c}\text { Epigenetic Inheritance } \\
\text { Mechanism }\end{array}$ & Heritable Effect & Reference \\
\hline \multirow{7}{*}{$\begin{array}{c}\text { C5-cytosine } \\
\text { methylation/demethylation }\end{array}$} & Phase variation & Pearson (2019) [17] \\
\hline & Inheritance of methylated Cori ${ }^{*}$ & Frandi \& Collier (2019) [18] \\
\hline & Epimutations & Skinner et al. (2019) [19] \\
\hline & Paramutations & House \& Lukens (2019) [20] \\
\hline & Genomic imprinting & Tucci et al. (2019) [21] \\
\hline & Transcriptional silencing & Di Felice et al. (2019) [22] \\
\hline & $\mathrm{X}$ chromosome inactivation & Żylicz et al. (2019) [23] \\
\hline \multirow{2}{*}{ Histone modifications } & Dosage compensation & Shevchenko et al. (2019) [24] \\
\hline & Vernalization & Zhong et al. (2019) [25] \\
\hline \multirow{2}{*}{$\begin{array}{l}\text { Post-transcriptional silencing } \\
\text { through RNA interference }\end{array}$} & $\begin{array}{l}\text { Transgenerational inheritance of } \\
\text { neural processes }\end{array}$ & Posner et al. (2019) [26] \\
\hline & Heritable effects of starvation & Dupont et al. (2019) [27] \\
\hline
\end{tabular}

*Chromosome replication origin.

Insect species reduction in diversity and population abundance has been accompanied by the demise of several other associated organisms (including symbionts), in what has been called the sixth mass extinction [28-33]. Several factors contributing to biodiversity loss are derived from the application of technological packages associated with human activities such as extractive and industrial production as well as industrialized intensive agriculture [34]. The contamination from chemicals incorporated during agricultural field management (e.g., pesticides and fertilizers) has been found to be one of the most harmful to the environment and human health [35-37]. These alterations increase the threats to a wide range of organisms, from beneficial soil microorganisms to our own species [38-40]. Pesticides can cause chronic adverse health effects due to altered gene expression mediated by EMM, e.g., C5-cytosine methylation (hereafter "DNAm") [35]. Several negative effects of sub-lethal doses of pesticides have been observed in the western honeybee, Apis mellifera (Hymenoptera: Apidae), which include reduced fecundity of queens; impaired immune response; flawed navigation and learning ability; and physiological, reproductive, and developmental negative side effects [41,42]. Pesticides have also been linked to DNAm alterations in bees [41]. Similar perturbations of biological processes have been observed in ground-nesting and solitary bees, with decreases in brood production and larval hatching as well as impaired foraging behavior [43]. EMMs have been proposed to provide resilience 
to environmentally derived stresses, including pesticides. It has been demonstrated that insects may be capable of developing resistance to anthropogenic chemical contaminants thanks to epigenetic modifications [44-46]. This has been found in several pest insects, where being exposed to these chemical formulations allows these pests to tolerate other sources of stresses [44]. This suggests that anthropogenic stress not only may be directly harmful to native insects but also may promote the rapid evolution of resistance in pest species. As a consequence, biodiversity and the further homogenization of industrial agriculturally managed land have seen steady declines [47].

Here, we review the current knowledge about EMMs in insect biology considering the epigenetic effects of different anthropogenic contaminants, with special emphasis on pesticides. We review in detail the case of the neuro-active neonicotinoid insecticides in non-target insect species and their relation to the decline in managed and wild bee species, drawing a potential link between EMMs and pesticide contamination and explaining colony collapse disorder [41,48]. Finally, we discuss the relationship between EMM responses to anthropogenic contamination and their potential role in the context of the sixth mass extinction [32].

\section{Epigenetic Molecular Mechanisms}

As previously mentioned, epigenetics focuses on the study of molecular interactions that modify gene expression both during cells' differentiation as well as later in the life of an organism, during cells' quiescence [49]. Epigenetic patterns are mainly defined as the result of the interaction of individuals with their surrounding environment [50]. EMMs include many processes involving biochemical reactions, with the collaboration of different biomolecules in living organisms capable of generating transient or heritable changes in gene expression [1,51]. A broad distinction can be made between pre- and post-transcriptional epigenetic mechanisms, depending on the levels in which they act upon gene expression. The former chemically modifies DNA nucleotides or the tails of histone proteins that wrap DNA around the nucleosome to form chromatin [6]. The most studied EMMs are DNAm (Figure 1), histone acetylation/deacetylation, histone methylation, histone phosphorylation, and histone ubiquitination (Figure 2) [52,53]. In contrast, a large number of known posttranscriptional mechanisms are associated with RNA, including transcripts, messenger (mRNAs), and non-coding (miRNAs, sRNAs, and lncRNA) [54-58]. Figure 3 shows miRNA transcription repression.

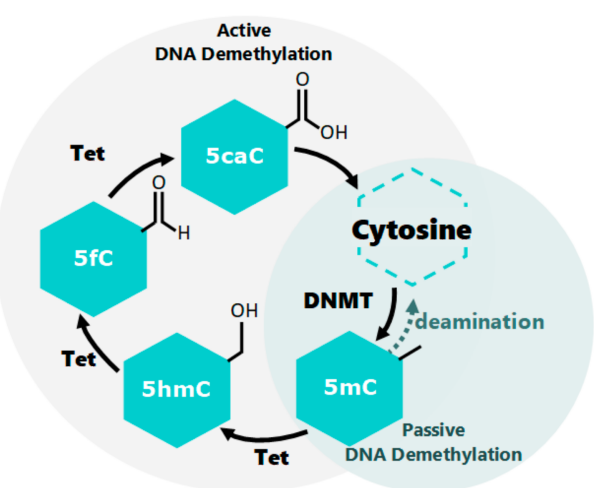

Figure 1. DNA demethylation and methylation: DNAm in eukaryotes occurs mainly at cytosine's fifth carbon atom, catalyzed by de novo methyltransferases (DNMT). Active DNA demethylation involves the successive oxidation of the 5-methyl-cytosine (5- $m C$ ) to 5-hydroxymethyl-cytosine (5$h m C$ ), to 5-formyl-cytosine (5-fC), and then to 5-carboxy-cytosine (5-caC), catalyzed by the Ten-eleven translocation enzyme family (Tet). Passive DNA demethylation occurs during replication due to the absence of methylation by DNMT1 across several rounds of replication. Figure by Gabriela Olivares-Castro [59,60]. 


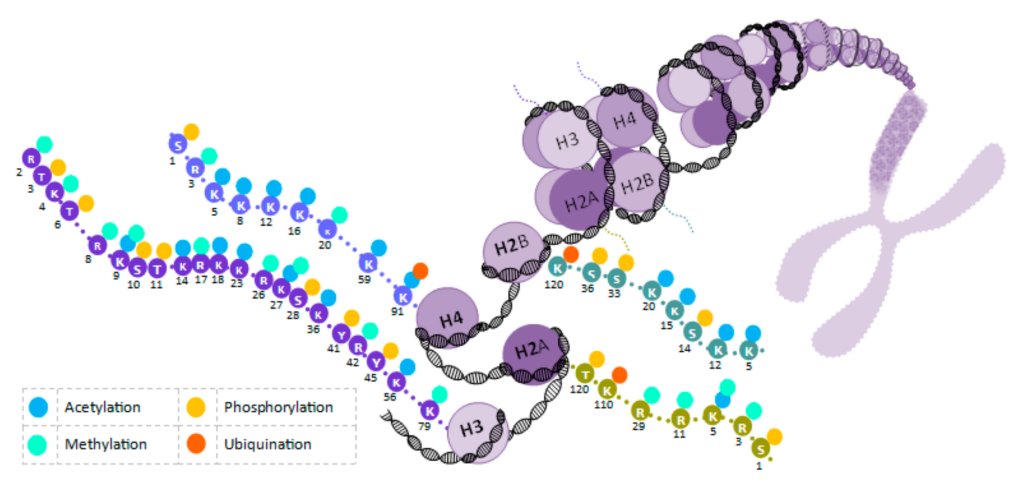

Figure 2. Histone modifications: Histones are proteins that package DNA into nucleosomes. Every nucleosome contains two subunits each of histones $\mathrm{H} 2 \mathrm{~A}, \mathrm{H} 2 \mathrm{~B}, \mathrm{H} 3$, or H4. These histones have an $\mathrm{N}$-terminal tail where the covalent modifications preferentially occur. These modifications can be acetylation/deacetylation, methylation, phosphorylation, or ubiquinitation. All of these modifications can be related to different effects on the biology of the organism. Histone acetylation is triggered by the addition of an acetyl group and is involved in various cell processes such as chromatin dynamics and transcription, and apoptosis, among others. Histone methylation occurs via the addition of a methyl group and causes transcription repression or activation, depending on target sites. Histone phosphorylation happens when a phosphate group is added to the histone; it is involved in DNA repair, cell cycle progression, chromosome condensation, and apoptosis. Histone ubiquitination happens with the transport of ubiquitin to the histone core proteins and can either activate or inhibit target gene expression, depending on which histone is affected. Figure by Gabriela Olivares-Castro [61].

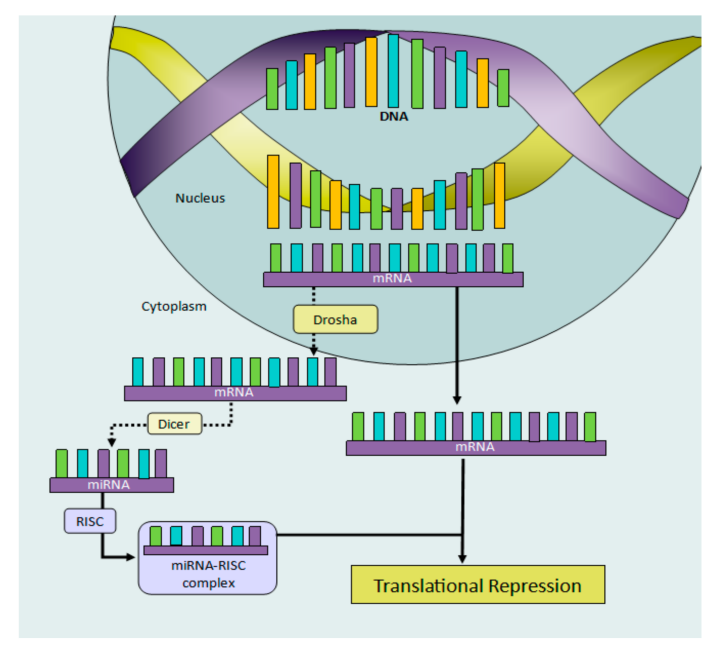

Figure 3. miRNA translational repression: to block protein expression, miRNA target mRNA and bind to them, preventing translation. Inside the nucleus, primary miRNA are cleaved by RNase III Drosha to produce smaller precursors of 60-70 nucleotides, which then translocate to the cytoplasm. Once there, the precursors are processed by another RNase III Dicer, which generates a duplex RNA of $\sim 22$ nucleotides. One strand is degraded, and the other is incorporated into the RNA-induced silencing complex (RISC), where it binds to the $3^{\prime}$ untranslated region of complementary mRNA. As a consequence, this may result either in its degradation and/or reduced translation, which has been proposed to lead to translational repression. Figure by Gabriela Olivares-Castro [62].

The epigenome comprises all of the epigenetic modifications associated with a given genome in the form of chemical modifications of DNA and histone tails [63]. There are five environmental factors that define the origin and maintenance of epigenome modifications: behavior, stress (both biotic and abiotic), nutrition, toxin exposure, and stochasticity (in the placement of methylation marks). All of these factors are especially relevant during early developmental stages [64]. Figure 4 shows the main factors reported to be associated with EMMs in insects: DNAm, histone modifications, and micro-RNA (miRNA) interference. 


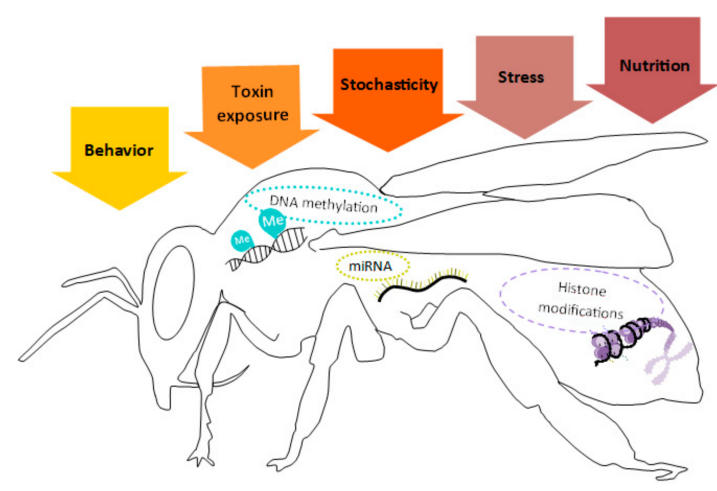

Figure 4. Environmental factors that trigger epigenetic mechanisms: Schematic representation of an insect (represented by a bee silhouette) illustrating the main EMMs found. The colored arrows denote the five main environmental factors that have been described in the literature that trigger the different epigenetic responses in the organism. These responses may be pre-transcriptional such as DNAm and histone modifications, or post-transcriptional such as miRNA interference. Figure by Gabriela Olivares-Castro [64].

Recent insightful reviews of EMMs illustrate current advances in the study of epigenetic modifications in insects $[2,7,65,66]$. It has been found that EMMs generally allow for the development of biological responses to environmental challenges, including those of anthropogenic origin. An example of these are EMM-related pesticide resistance, which has been observed from aphids to mosquitoes [45]. EMMs can also play a role in the protection of inheritance. For example, EEMs have been shown to be highly involved in insect transposon silencing through their potential to suppress genome rearrangements [54].

DNA expression changes induced by EMMs can be inherited by the descendants of the exposed individuals through transgenerational epigenetic inheritance, which bypasses the reprogramming of DNAm and chromatin proteins during meiosis [67]. Some authors consider that the heritability of epigenetic changes, either as a cell lineage effect or in a transgenerational sense, is their defining quality [64]. An extensive recent review on the subject of epigenetic inheritance by Tikhodeyev [68] describes ten different mechanisms of stable allelic epigenetic inheritance (SAEI) and discusses two other possible mechanisms. In Table 1, we provide an updated version of Tikhodeyev's summary of different mechanisms of epigenetic inheritance, in which we incorporate recent examples of SAEI, focusing on the three main epigenetic mechanisms discussed in this work.

\section{Insect Epigenetics and Contamination}

Genetics has benefited greatly from the study of various insect models (class Insecta), which have been used in the discovery and characterization of different molecular mechanisms [66,69-75]. Major topics in biology have been enriched by the feedback from the study of insect EMMs, such as cell biology, development, and evolution [54]. For example, epigenetics has contributed to enriching explanations regarding the mechanisms underlying polymorphisms such as sociality in insects, where EMMs have been shown to be relevant in explaining caste differentiation [76,77]. EMMs have also contributed to explaining how environmental influences alter different aspects of phenotypes without modifying genotypes [78].

The study of anthropogenically derived influences as epigenetic stimuli, such as pollution and climate change, are among the fast-growing areas of interest within insect EMMs [79-81]. The goal of these studies is to assess how stressors may affect different ecological levels [82], considering exposure to pesticides [41,44,83], endocrine disruptors [11,84,85], heavy metals [84,86,87], or temperature changes [88] as triggers of epigenetic changes. In Table 2, we summarize the different responses of insect biology to different kinds of toxicants and whether there is evidence of the role of EMMs in these processes. 


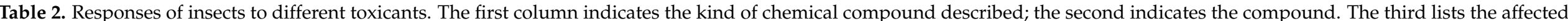

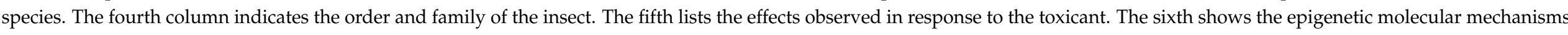

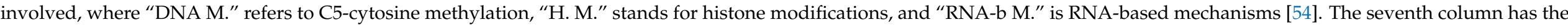
corresponding references cited.

\begin{tabular}{|c|c|c|c|c|c|c|}
\hline $\begin{array}{l}\text { Chemical Group/ } \\
\text { Functional Category }\end{array}$ & Elements or Compounds & Affected Species & Order: Family & Effects & EMMs Studied & References \\
\hline \multirow{4}{*}{ Heavy Metals } & $\mathrm{Cu}^{2+}$ & $\begin{array}{c}\text { Aedes aegypti; } \\
\text { Anopheles arabiensis }\end{array}$ & Diptera: Culicidae & $\begin{array}{l}\text { Cell metabolisms, egg hatching, } \\
\text { apoptosis; decrease in RNA } \\
\text { methylation; DNAm methylation }\end{array}$ & $\begin{array}{l}\text { DNA M., } \\
\text { RNA-b M }\end{array}$ & $\begin{array}{c}\text { Rayms-Keller et al., } 2000 \text { [89]; } \\
\text { Raes et al., } 2000 \text { [90]; } \\
\text { Jeanrenaud, Brooke \& Oliver, } \\
2020 \text { [84] }\end{array}$ \\
\hline & $\mathrm{Zn}$ & Rhithrogena robusta & $\begin{array}{l}\text { Ephemeroptera: } \\
\text { Heptageniidae }\end{array}$ & Reduced individual growth rate & $\mathrm{NO}$ & Carlisle \& Clements, 2003 [91] \\
\hline & $\mathrm{Pb}$ & $\begin{array}{l}\text { Lymantria dispar; } \\
\text { Anopheles arabiensis }\end{array}$ & $\begin{array}{l}\text { Lepidoptera: Erebidae; } \\
\text { Diptera: Culicidae }\end{array}$ & $\begin{array}{l}\text { Decrease in growth and reduction } \\
\text { in hatching success; increased in } \\
\text { RNA methylation patterns; } \\
\text { DNA methylation }\end{array}$ & $\begin{array}{l}\text { DNA M., } \\
\text { RNA-b M. }\end{array}$ & $\begin{array}{c}\text { Gintenreiter, Ortel \& Nopp, } \\
1993 \text { [87]; Jeanrenaud, Brooke } \\
\text { \& Oliver, } 2020 \text { [84] }\end{array}$ \\
\hline & $\mathrm{Cd}$ & $\begin{array}{l}\text { Orchesella cincta; } \\
\text { Anopheles arabiensis }\end{array}$ & $\begin{array}{c}\text { Collembola: } \\
\text { Entomobryidae; } \\
\text { Diptera: Culicidae }\end{array}$ & $\begin{array}{l}\text { Transcriptome stress response; } \\
\text { increase in 5-hmC methylation }\end{array}$ & DNA M. & $\begin{array}{c}\text { Roelofs et al., } 2009 \text { [86]; } \\
\text { Jeanrenaud, Brooke \& Oliver, } \\
2020 \text { [84] }\end{array}$ \\
\hline Heavy Metals & $\mathrm{Al}$ & $\begin{array}{l}\text { Drosophila } \\
\text { melanogaster }\end{array}$ & Diptera: Drosophilidae & $\begin{array}{l}\text { Reduction in median life span; } \\
\text { climbing ability and } \\
\text { cognitive capacity }\end{array}$ & $\mathrm{NO}$ & Wu et al., 2012 [92] \\
\hline \multirow{4}{*}{$\begin{array}{l}\text { Chlorinated } \\
\text { hydrocarbons }\end{array}$} & DDT & $\begin{array}{l}\text { Ephemerella subvaria, } \\
\text { Ephemerella auravillii }\end{array}$ & $\begin{array}{l}\text { Ephemeroptera: } \\
\text { Ephemerellidae }\end{array}$ & Impaired subimago emergence & NO & Hitchcock, 1965 [93] \\
\hline & Aldrin & Cheumatopsyche analis & $\begin{array}{c}\text { Trichoptera: } \\
\text { Hydropsychidae }\end{array}$ & Hormetic response & $\mathrm{NO}$ & Moye \& Luckmann, 1964 [94] \\
\hline & Chlordane & Periplaneta americana & Blattodea: Blattidae & $\begin{array}{l}\text { Increase in total hemocyte count; } \\
\text { excessive vacuolization of epithelial } \\
\text { cells in the midgut lumen }\end{array}$ & $\mathrm{NO}$ & Gupta \& Sutherland, 1968 [95] \\
\hline & Endrin & Periplaneta americana & Blattodea: Blattidae & $\begin{array}{l}\text { Dose-dependent blocking of } \\
\text { GABA receptors }\end{array}$ & $\mathrm{NO}$ & Wafford et al., 1989 [96] \\
\hline
\end{tabular}


Table 2. Cont.

\begin{tabular}{|c|c|c|c|c|c|c|}
\hline $\begin{array}{l}\text { Chemical Group/ } \\
\text { Functional Category }\end{array}$ & Elements or Compounds & Affected Species & Order: Family & Effects & EMMs Studied & References \\
\hline \multirow{2}{*}{$\begin{array}{l}\text { Chlorinated } \\
\text { hydrocarbons }\end{array}$} & Heptachlor & Periplaneta americana & Blattodea: Blattidae & $\begin{array}{l}\text { Dose-dependent blocking of } \\
\text { GABA receptors }\end{array}$ & $\mathrm{NO}$ & Lummis et al., 1990 [97] \\
\hline & Lindane & $\begin{array}{l}\text { Periplaneta americana; } \\
\text { Chironomus ripariu }\end{array}$ & $\begin{array}{l}\text { Blattodea: Blattidae; } \\
\text { Diptera: Chironimidae }\end{array}$ & $\begin{array}{l}\text { Dose-dependent blocking of GABA } \\
\text { receptors; reduction in } \\
\text { imago emergence }\end{array}$ & $\mathrm{NO}$ & $\begin{array}{l}\text { Wafford et al., } 1989 \text { [96]; } \\
\text { Maund et al., } 1992 \text { [98] }\end{array}$ \\
\hline \multirow{3}{*}{ Organophosphates } & Parathion & Musca domestica & Diptera: Muscidae & Toxin degradation & $\mathrm{NO}$ & $\begin{array}{c}\text { Matsumura \& Hogendijk, } \\
1964 \text { [99] }\end{array}$ \\
\hline & Malathion & $\begin{array}{l}\text { Periplaneta americana; } \\
\text { Musca domestica }\end{array}$ & $\begin{array}{l}\text { Blattodea: Blattidae; } \\
\text { Diptera: Muscidae }\end{array}$ & Toxin metabolization & $\mathrm{NO}$ & Krueger \& O’Brien, 1959 [100] \\
\hline & Glyphosate & Deleatidium spp. & $\begin{array}{l}\text { Ephemeroptera: } \\
\text { Leptophlebiidae }\end{array}$ & Reduction in imago emergence & $\mathrm{NO}$ & Magbanua et al., 2016 [101] \\
\hline \multirow{6}{*}{ Organophosphates } & Diazinon & Musca domestica & Diptera: Muscidae & Toxin degradation & $\mathrm{NO}$ & $\begin{array}{c}\text { Matsumura \& Hogendijk, } \\
1964 \text { [99] }\end{array}$ \\
\hline & Tetrachlorvinphos & Alphitobius diaperinus & $\begin{array}{l}\text { Coleoptera: } \\
\text { Tenebrionidae }\end{array}$ & Resistance to pesticide & $\mathrm{NO}$ & Hamm et al., 2006 [102] \\
\hline & Azamethiphos & Musca domestica & Diptera: Muscidae & Resistance to pesticide & $\mathrm{NO}$ & Kristensen et al., 2000 [103] \\
\hline & Phosmet & Megachile rotundata & $\begin{array}{l}\text { Hymenoptera: } \\
\text { Megachilidae }\end{array}$ & $\begin{array}{l}\text { Reduced nesting and } \\
\text { progeny production }\end{array}$ & $\mathrm{NO}$ & Alston et al., 2007 [104] \\
\hline & Diclorvos & Alphitobius diaperinus & $\begin{array}{l}\text { Coleoptera: } \\
\text { Tenebrionidae }\end{array}$ & Resistance to pesticide & $\mathrm{NO}$ & $\begin{array}{c}\text { Chernaki-Leffer et al., } \\
2011 \text { [105] }\end{array}$ \\
\hline & Terbufos & Alphitobius diaperinus & $\begin{array}{c}\text { Diptera: } \\
\text { Sarcophagidae }\end{array}$ & Avoidance of pesticide & $\mathrm{NO}$ & Jales et al., 2020 [106] \\
\hline
\end{tabular}


Table 2. Cont.

\begin{tabular}{|c|c|c|c|c|c|c|}
\hline $\begin{array}{l}\text { Chemical Group/ } \\
\text { Functional Category }\end{array}$ & Elements or Compounds & Affected Species & Order: Family & Effects & EMMs Studied & References \\
\hline \multirow{4}{*}{ Carbamates } & Sevin & Musca domestica & Diptera: Muscidae & Metabolization of pesticide & NO & $\begin{array}{c}\text { Eldefrawi \& Hoskims, } \\
1964 \text { [107] }\end{array}$ \\
\hline & Aldicarb & $\begin{array}{l}\text { Pseudatomoscelis } \\
\text { seriatus; } \text { Musca } \\
\text { domestica }\end{array}$ & $\begin{array}{l}\text { Hemiptera: Miridae; } \\
\text { Diptera: Muscidae }\end{array}$ & Death & $\mathrm{NO}$ & $\begin{array}{l}\text { Davis \& Cowan, } 1972 \text { [108]; } \\
\text { Spurr \& Sousa, } 1974 \text { [109] }\end{array}$ \\
\hline & Carbofuran & Diabrotica virgifera & $\begin{array}{l}\text { Coleoptera: } \\
\text { Chrysomelidae }\end{array}$ & $\begin{array}{l}\text { Increase in oviposition; increase } \\
\text { in longevity }\end{array}$ & $\mathrm{NO}$ & Ball \& Su, 1979 [110] \\
\hline & Carbaryl & Diabrotica virgifera & $\begin{array}{l}\text { Coleoptera: } \\
\text { Chrysomelidae }\end{array}$ & Increase in oviposition & NO & Ball \& Su, 1979 [110] \\
\hline \multirow{5}{*}{ Pyrethroids } & Allethrin & Periplaneta americana & Blattodea: Blattidae & $\begin{array}{l}\text { Temperature dependent disruption } \\
\text { of the nervous system }\end{array}$ & NO & Gammon, 1978 [111] \\
\hline & Bifenthrin & Apis mellifera ligustica & Hymenoptera: Apidae & $\begin{array}{l}\text { Reduction in oviposition; reduction } \\
\text { in cap rate; reduction in emergence } \\
\text { rate; success rate of development }\end{array}$ & $\mathrm{NO}$ & Dai et al., 2010 [112] \\
\hline & $\beta$ Cyfluthrin & $\begin{array}{c}\text { Drosophila } \\
\text { melanogaster } \\
\text { (Sepia mutant) }\end{array}$ & Diptera: Drosophilidae & $\begin{array}{l}\text { Reduction imago emergence; } \\
\text { prolongation of total } \\
\text { developmental period }\end{array}$ & NO & $\begin{array}{c}\text { Nadda, Saxena \& Srivastava, } \\
2005 \text { [113] }\end{array}$ \\
\hline & Cypermethrin & Alphitobius diaperinus & $\begin{array}{l}\text { Coleoptera: } \\
\text { Tenebrionidae }\end{array}$ & Resistance to pesticide & NO & $\begin{array}{l}\text { Chernaki-Leffer et al., } \\
2011 \text { [105] }\end{array}$ \\
\hline & Cyphenothrin & Ranatra filiformis & Hemiptera: Nepidae & Hyperactivity, death & $\mathrm{NO}$ & Saha \& Kaviraj, 2007 [114] \\
\hline \multirow{4}{*}{ Pyrethroids } & Deltamethrin & Apis mellifera ligustica & Hymenoptera: Apidae & $\begin{array}{l}\text { Reduction in oviposition; lower } \\
\text { hatch rate; reduction in cap rate; } \\
\text { success rate of development }\end{array}$ & $\mathrm{NO}$ & Dai et al., 2010 [112] \\
\hline & Permethrin & Acheta domesticus & Orthoptera: Gryllidae & Death & $\mathrm{NO}$ & Schleier \& Peterson, 2010 [115] \\
\hline & Resmethrin & Danaus plexippus & $\begin{array}{l}\text { Lepidoptera: } \\
\text { Nymphalidae }\end{array}$ & Reduced adult size, death & $\mathrm{NO}$ & Oberhauser et al., 2009 [116] \\
\hline & Transfluthrin & Culex tarsalis & Diptera: Culicidae & Avoidance of pesticide & $\mathrm{NO}$ & Britch et al., 2020 [117] \\
\hline
\end{tabular}


Table 2. Cont.

\begin{tabular}{|c|c|c|c|c|c|c|}
\hline $\begin{array}{l}\text { Chemical Group/ } \\
\text { Functional Category }\end{array}$ & Elements or Compounds & Affected Species & Order: Family & Effects & EMMs Studied & References \\
\hline $\begin{array}{l}\text { Neonicotinoids } \\
\text { (neuroinsecticides) }\end{array}$ & Thiamethoxam & Musca domestica & Diptera: Muscidae & $\begin{array}{c}\text { Acetylcholine receptors } \\
\text { hyperexcitation; ATPase activity }\end{array}$ & NO & $\begin{array}{l}\text { Abdel-Haleem et al., } \\
2018 \text { [118] }\end{array}$ \\
\hline \multirow{6}{*}{$\begin{array}{l}\text { Neonicotinoids } \\
\text { (neuroinsecticides) }\end{array}$} & Imidacloprid & Apis mellifera & Hymenoptera: Apidae & $\begin{array}{l}\text { Acetylcholine receptors } \\
\text { hyperexcitation; Malpighian tubule } \\
\text { deformation; changes in global } \\
\text { DNA methylation }\end{array}$ & DNA M. & $\begin{array}{c}\text { Paleolog et al., } 2020 \text { [119]; } \\
\text { Hu et al., 2018 [120]; } \\
\text { Brevik et al., } 2020 \text { [81] }\end{array}$ \\
\hline & Acetamiprid & Apis mellifera & Hymenoptera: Apidae & $\begin{array}{l}\text { Reduction in sucrose sensitivity; } \\
\text { increased locomotive activity }\end{array}$ & $\mathrm{NO}$ & El-hassani et al., 2007 [121] \\
\hline & Clothianidin & Chironomus dilutus & Diptera: Chironomidae & Reduction of emergence & $\mathrm{NO}$ & Maloney et al., 2018 [122] \\
\hline & Nitenpyram & $\begin{array}{l}\text { Bemisia tabaci } B \\
\text { biotype }\end{array}$ & $\begin{array}{l}\text { Hemiptera: } \\
\text { Aleyrodidae }\end{array}$ & Resistance to pesticide & $\mathrm{NO}$ & Liang et al., 2012 [123] \\
\hline & Thiacloprid & Culex pipiens & Diptera: Culicidae & Preimaginal development duration & $\mathrm{NO}$ & Beketov \& Liess, 2008 [124] \\
\hline & Dinotefuran & Chironominae spp. & Diptera: Chironomidae & Population hormetic response & $\mathrm{NO}$ & Kobashi et al., 2017 [125] \\
\hline \multirow{6}{*}{$\begin{array}{l}\text { Endocrine disruptors } \\
\text { (ED) }\end{array}$} & Bisphenol A & Chironomus riparius & Diptera: Chironomidae & $\begin{array}{l}\text { Increase in mRNA for ecdysone } \\
\text { receptor and increase in the } \\
\text { expression of HSP70 }\end{array}$ & RNA-b M. & $\begin{array}{c}\text { Planelló, Martínez-Guitarte \& } \\
\text { Morcillo, } 2008 \text { [85] }\end{array}$ \\
\hline & Tributyltin & Chironomus riparius & Diptera: Chironomidae & DNA breakage & $\mathrm{NO}$ & Martínez-Paz et al., 2013 [126] \\
\hline & Pentachlorophenol & Chironomus riparius & Diptera: Chironomidae & $\begin{array}{l}\text { Upregulation of Hsp70 gene } \\
\text { transcription; downregulation of } \\
\text { the Hsp27 transcription }\end{array}$ & $\mathrm{NO}$ & Morales et al., 2014 [127] \\
\hline & Nonylphenol & Chironomus riparius & Diptera: Chironomidae & DNA breakage & $\mathrm{NO}$ & Martínez-Paz et al., 2013 [126] \\
\hline & Triclosan & Chironomus riparius & Diptera: Chironomidae & DNA breakage & $\mathrm{NO}$ & Martínez-Paz et al., 2013 [126] \\
\hline & Benzyl butyl phthalate & Chironomus riparius & Diptera: Chironomidae & Overexpression of the EcR gene & $\mathrm{NO}$ & Planelló et al., 2011 [128] \\
\hline
\end{tabular}


Table 2. Cont

\begin{tabular}{|c|c|c|c|c|c|c|}
\hline $\begin{array}{l}\text { Chemical Group/ } \\
\text { Functional Category }\end{array}$ & Elements or Compounds & Affected Species & Order: Family & Effects & EMMs Studied & References \\
\hline \multirow{5}{*}{$\begin{array}{l}\text { Endocrine disruptors } \\
\text { (ED) }\end{array}$} & $\begin{array}{l}\mathrm{DEHP} / \mathrm{Di}(2- \\
\text { ethylhexyl)phthalate }\end{array}$ & Chironomus riparius & Diptera: Chironomidae & Mouthparts deformities & NO & Park \& Kwak, 2008 [129] \\
\hline & Ethinylestradiol & $\begin{array}{l}\text { Drosophila } \\
\text { melanogaster }\end{array}$ & Diptera: Drosophilidae & $\begin{array}{l}\text { Reduction in lifespan, decrease } \\
\text { in fertility }\end{array}$ & $\mathrm{NO}$ & Bovier et al., 2018 [130] \\
\hline & $\begin{array}{l}\text { Genistein/5,7-dihydroxy- } \\
\text { 3-(4-hydro- } \\
\text { xyphenyl)chromen-4-one) }\end{array}$ & $\begin{array}{l}\text { Aedes albopictus; } \\
\text { Anopheles arabiensis }\end{array}$ & Diptera: Culicidae & $\begin{array}{l}\text { DNA methylation; reduction in } \\
\text { egg hatching }\end{array}$ & DNA M. & $\begin{array}{c}\text { Oppold et al., } 2015 \text { [11]; } \\
\text { Jeanrenaud, Brooke \& Oliver, } \\
2020 \text { [84] }\end{array}$ \\
\hline & Vinclozolin (Fungicide) & $\begin{array}{l}\text { Aedes albopictus; } \\
\text { Anopheles arabiensis }\end{array}$ & Diptera: Culicidae & $\begin{array}{l}\text { DNA methylation; reduction in } \\
\text { egg hatching }\end{array}$ & DNA M. & $\begin{array}{c}\text { Oppold et al., } 2015 \text { [11]; } \\
\text { Jeanrenaud, Brooke \& Oliver, } \\
2020 \text { [84] }\end{array}$ \\
\hline & $\begin{array}{l}\text { DMSO/dimethyl } \\
\text { sulphoxide }\end{array}$ & Antheraea assamensis & $\begin{array}{l}\text { Lepidoptera: } \\
\text { Saturniidae }\end{array}$ & $\begin{array}{l}\text { Alterations in hormonal balance; } \\
\text { alterations in silk production }\end{array}$ & $\mathrm{NO}$ & Unni et al., 2009 [131] \\
\hline \multirow{2}{*}{ Micro plastics } & Polystyrene & Culex pipiens & Diptera: Culicidae & $\begin{array}{l}\text { Accumulation in } \\
\text { Malpighian tubules }\end{array}$ & $\mathrm{NO}$ & $\begin{array}{l}\text { Al-Jaibachi, Cuthbert \& } \\
\text { Callaghan, } 2018 \text { [132] }\end{array}$ \\
\hline & $\begin{array}{l}\text { Acrylonitrile butadiene } \\
\text { styrene (ABS) }\end{array}$ & Siphlonurus sp. & $\begin{array}{l}\text { Ephemeroptera: } \\
\text { Siphlonuridae }\end{array}$ & Accumulation in body & $\mathrm{NO}$ & $\begin{array}{c}\text { Akindele, Ehlers \& Koop, } \\
2020 \text { [133] }\end{array}$ \\
\hline
\end{tabular}


Besides direct lethality, a wide array of sub-lethal effects has been described in insect biology in response to different levels of exposure to environmental toxicants [134-138]. Population hormetic responses appear after an organism is stimulated by a relatively low dose of a stressor; thus, this may enhance their chances of survival under the pressure of this environmental stress source [125]. For example, exposure to sub-lethal pesticide traces can induce changes such as a reduction in sucrose sensitivity [121], a deformation of the Malpighian tubules [120], or the development of resistance towards the pesticide $[102,105,123]$. Although some of these effects have been linked to EMMs by previous researchers [54,120], there are other responses towards different pesticides where it is possible to hypothesize the involvement of EMMs $[83,139]$, for instance, the activation of the cytochrome $\mathrm{P}_{450}$ monooxygenase (CYP450) pathway after exposure to a low dose of pesticide [83].

Over half of the studies shown in Table 2 were conducted on dipterans as model organisms, with considerable focus on species with aquatic phases during development such as mosquitoes (e.g., $[11,84,132])$. Of all the toxicants reviewed, the only group without studies in aquatic environments is the carbamate cholinesterase inhibitors, a group of organic compounds derived from carbamic acid $\left(\mathrm{NH}_{2} \mathrm{COOH}\right)$ found in broad-spectrum pesticides (e.g., [107-110]). Despite the concern raised about carbamides and their effects on human health $[36,140]$, this group is one of the least studied regarding their effect on biodiversity, including arthropods [141]. Carbamates have been found among the cocktail of contaminants detected in irrigation water sources, along with other pesticides, microplastics, and pharmaceutical residues. Importantly, these contaminants may exert synergistic negative effects on aquatic organisms [142].

Organophosphates such as diazinon and glyphosate have shown remarkably high sorption and irreversible sorption in allophanic agricultural soils [143,144]. It has been reported that glyphosate has consequences at the ecosystem level, affecting the soil and water sources due to its leaching from the soil [143]. Evidence also shows glyphosate teratogenicity in vertebrates including our own species, reporting unwanted effects in nontarget organisms for GPS ranging from physiological abnormalities to carcinogenesis [143]. GPS also affects the intestinal microorganisms of bees, increasing the mortality of native bees [137].

Only $20 \%$ of the studied organisms in Table 2 are native species, with none of the studies exploring the involvement of EMM responses to toxicants, contrasting with $40 \%$ of studies considering plague organisms and $40 \%$ conducted on model species. These values reflect how limited the currently available information is on these kinds of effects in native species regarding pesticides and other toxins, an aspect that should be further explored if loss of biodiversity is to be addressed.

In contrast, endocrine disruptors are the group with the most studies in insects, about $22.4 \%$ of reviewed articles, with the majority from aquatic environments, followed closely by organophosphates with $17.2 \%$. The most frequently observed effects in these cases were epigenetic modifications as well as changes in fertility and egg hatching. DNAm was the most frequently observed of the EMMs reviewed in Table 2, being described in dipterans of the culicid and chironomid families as well as in hymenopterans such as honeybees. RNA-based modifications were also described in aquatic dipterans from the culicid and chironomid families, reinforcing the importance of aquatic organisms in toxicological research. It is relevant to highlight that most of the consequences of the contaminants reviewed can be categorized as sub-lethal alterations. This stresses the need to reconsider the protocols broadly used to assess the effects of pesticide toxicants on study organisms for further applied use in agriculture farmlands and urban environments, as sub-lethal exposure is the most likely source of EMM-related alterations, since a "sub-lethal" exposure to contaminants is capable not only of generating detrimental environmentally induced effects in the organisms directly affected but also in their progeny. This may result in pervasive transgenerational alterations to insect populations and species. 
Even in the cases where effects on EMMs in response to a specific chemical have not been studied, it is possible to hypothesize their potential involvement in several of the phenotypic alterations detected due to exposure to contaminants (Table 2). This can be achieved through comparing similar effects of contaminants in the focal species previously investigated, where phenotypic alterations (e.g., physiological) had a clear link with EMMs [54]. This approach may help to identify further links between humanderived pollution and EMMs to be explored in future studies. The participation of EMMs as regulators of insect responses to pesticides can also be inferred by analyzing the methylome and genome in specific experimental situations such as resistance to a certain chemical [145].

Different innovative approaches are being employed to address this problem, such as in vitro studies using vertebrate and invertebrate model organisms. Several of these toxicants have been identified as capable of affecting epigenetic states in humans $[60,140,146]$. In the following section, we delve into the interactions between pesticides and the environmEntomol.

\section{Pesticide Chemical Behavior in the Environment}

Pesticides include many classes of chemicals used to control undesirable target species such as agricultural or household pests [147]. These can be chemical extracts derived from the metabolites of different organisms such as pyrethrins [148] and neem seed oil [149]. However, most pesticides used are synthetic chemical formulations massively produced and distributed by pharmaceutical companies [150]. As has been extensively demonstrated and reviewed, pesticides not only harm the intended target species but also, most of the time, can exert negative effects on a diversity of other non-target life forms exposed to them, including humans [3,151-153]. Pesticide formulations have been found to have adverse consequences in the central nervous system; cognitive abilities and behavior; reproduction; endocrine regulation; development; the promotion of diseases (e.g., cancer) [154-157]; and ultimately the survival of many organisms, including pollinators exposed to these agrochemicals $[135,158,159]$.

The global amount of pesticide application has remained constant during recent decades; nonetheless, it has been reported that the toxicity of these formulations has been increasing. The total worldwide expenditure in pesticides exceeded 56 billion USD in 2012. Herbicides are the dominant pesticide used to control weeds in agricultural production, accounting for the largest proportion (45\%) of total pesticide expenditure, followed by insecticides, fungicides, and other pesticides [160].

The main processes studied to evaluate the environmental fate of herbicides are sorption kinetics, sorption-desorption, degradation, biodegradation, bioavailability, and transport [161-163]. Sorption is the key parameter in evaluating the fate and behavior of herbicides in soils in relation to bioavailability, distribution, and transport to other environmental compartments [164]. The sorption process in soils is one of the most relevant aspects to consider for appropriate use of herbicides and their environmental fate. The chemical properties of herbicides together with the physical, chemical, and biological characteristics of soils influence their fate and behavior in soils [144].

Volcanic ash-derived soils (VADS) such as andisols generally have a high concentration of total phosphorus but not plant-available $\mathrm{P}$, so these soils require frequent adjustments of the soil $\mathrm{pH}$, replacement of exchangeable $\mathrm{Mg}$, and heavy $\mathrm{P}$ applications in order to yield crops [144]. These industrial agriculture amendments can increase the leaching potential of organophosphate herbicides such as glyphosate (GPS) (Table 2) that have been recently applied as a consequence of competition with phosphate for surface sites, an increase in negative charge on the surface resulting from phosphate sorption [165]. These aspects help to explain how pesticide residues can be adsorbed in the soil as well as can infiltrate into groundwater [122,166-169].

The broad-spectrum herbicide GPS is used non-selectively in agriculture to control weeds and herbaceous plants $[143,165]$. GPS sorption studies on VADS have reported that it is strongly adsorbed by mineral clays and organic matter (hereafter "OM") from agricultural VADS [143,165]. GPS has shown irreversible sorption in allophanic agricultural 
soils $[143,165]$. The exceptionally high sorption of GPS in ultisols has been related to kaolinite content and acidic $p H$ [165].

An excess of GPS sorption in unfertilized VADS may result in an unavailability of this herbicide to targeted pests as well as uneven distribution around the plants [170]; microbial degradation of this herbicide to its primary metabolites, glioxylate and aminomethylphosphonic acid (AMPA) [143,144,165]; alteration of soil microbiota; and adverse effects on multicellular species [171]. It has been reported that GPS has consequences at the ecosystem level, affecting the soil and water due to its leaching from the soil [143]. The contamination of water sources by pesticides may also trigger detrimental effects in several aquatic insects during early development stages $[170,172]$. Evidence also shows GPS teratogenicity in vertebrates, including our own species, reporting unwanted effects in non-target organisms ranging from physiological abnormalities to carcinogenesis [161]. GPS also affects the intestinal microorganisms of bees, increasing the mortality of native bees [143].

Similar patterns of environmental risks due to pesticide use have been reported for other formulations such as carbamates and neonicotinoid insecticides, which were initially considered not harmful but in which the risks are currently under question [173]. Carbamate insecticides (Table 2) have been found among the cocktail of contaminants detected in irrigation water sources, along with other pesticides, microplastics, and pharmaceutical residues. Importantly, these contaminants may exert synergistic negative effects on aquatic organisms [142].

Neonicotinoids such as acetamiprid (ACT) and imidacloprid (IMD) (Table 2) are insecticides widely used in agriculture [164]; they exert a powerful systemic action on insects for the protection of various crops against piercing and sucking pests, with low acute and chronic toxicity for mammals, birds, and fish [164,174]. Neonicotinoids usually have high water solubility and a low octanol-water partition coefficients $\left(K_{o w}\right)$ [164] and are not readily biodegradable [164]. All neonicotinoid insecticides are rather stable at acidic or neutral $p H$ and even at alkaline $p H$ (half-life from 11.5 to 420 days) [164], since they hydrolyze slowly. The half-lives of ACT and IMD are 3-8 weeks, and 13 and a half months, respectively [174]. These properties of neonicotinoid insecticides influence their fate in the environment, since between 2 and $20 \%$ of the active ingredient is adsorbed by the plant (depending on the type of crop), with an average adsorption of $5 \%$; thus, between $80 \%$ and $90 \%$, or even $>95 \%$ of the bulk active ingredient is spread in the environment and enters the soil or surface/ground water after planting [164,174].

Neonicotinoids easily diffuse into soils and waterways in agricultural settings and their neighboring areas through leaching and runoff from arable lands [174,175] due to their hydrophilic character and low potential for sorption to soil [174], raising concerns that they may pass into bodies of water and therefore can pose a risk for water quality. Neonicotinoids have been found in the aquatic environment in almost all continents at concentrations above the European Union (EU) legislation limits [164].

The amount of neonicotinoid sorption to soil increases with increasing soil OM content and a slower sorption rate due the presence of chemical non-equilibrium [161,174,175]. Neocotinoid sorption increases with the aging of soil residues due to sorption kinetic processes and diffusion of this kind of insecticides, which can lead to an unexpected persistence of neocotinoids in the environment, decreasing the potential risk of leaching to deeper layers [175].

It has been reported that the fraction of humic substances (HS) (HA, fulvic acids (FA), and humin $(\mathrm{HM})$ ) can be more important in determining neocotinoid sorption parameters given the high reactivity of HA and FA [174]. ACT has been mainly sorbed to HS fractions in soil; ACT has been sorbed in mineral particles, and $\mathrm{Al}^{3+}$ and $\mathrm{Fe}^{3+}$ ions through electrostatic interactions, but these play only a minor role in the ACT sorption process on soil under weakly acidic to neutral $p H$ [174]. 
All of this evidence shows how difficult it is to control the environmental fate of pesticides (or even to be able to track their contamination levels in soil, water, or air). In order to assess how common it is for different non-target species, from urban, rural, agricultural, and adjacent wild habitats, to suffer from pesticide contamination, it is key to understand the probability with which different pesticides end in non-desired places. Thus, the study of the link between pesticide environmental fate and sublethal effects on non-target organism is a must.

Sub-lethal effects on target pests are also an inevitable consequence of these applications. These exposures have been found to allow pests to develop resistance, for instance, through hermetic responses that have been also hypothesized to be linked with EMMs. This is developed further in the following section.

\section{Pesticide Effects on Pest and Non-Target Organisms}

Pesticides may control target pest species, leading to a temporal/local decline in these non-desired organisms but can also lead to the development of resistance, among a wide range of other possible responses [3,43,122,123,176-180]. Such a range of responses has to do with a variety of factors, from the type of organism being exposed to the dose and venue of exposure [32]. For instance, under intensive agriculture management, pesticides are often reapplied several times due to their natural decrease in availability over time. It has been reported that pests can develop resistance to formulations during periods of exposure to lower pesticide concentration $[10,44,181]$. It has also been described that the use of pesticides may end up helping the pest they were intended to combat by suppressing pest predators and competitors that are naturally available in the ecosystem. Outbreaks of new pests that were under control before the application of the pesticide can emerge due to the development of resistance against pesticides by the pest species $[3,43]$.

The exposure of non-target insects (such as parasitic wasps and social Hymenoptera) to sub-lethal levels of contamination may trigger several developmental and physiological alterations as well as may augment their susceptibility to develop diseases, thereby reducing their chances of survival $[12,182]$. The effects of pesticides on insects may depend, among other factors, on the mechanisms that the exposed organisms employ to process these toxicants [45]. These mechanisms include behavioral responses such as avoiding pesticides, metabolic adaptation to process toxic chemicals, epigenetic changes, and altered regulation of coding proteins $[43,45,54,85]$.

Insects are recognized as the main collaborators in nature's contribution to people, such as in food production [182]. For instance, data from USA show that the main crops produced are strongly dependent on insect pollination, where wild pollinators contribute to a large portion of the crop yield obtained [183]. This pattern is similar worldwide [184], even for crop species with autonomous self-reproduction [185]. This evidence stresses the need for understanding and considering the interaction of pesticides with pollinators. In the following section, we focus on neonicotinoid pesticides. Although these formulations were initially proposed as less harmful in comparison with other pesticide chemical formulations to non-target organisms such as insect pollinators, recent evidence demonstrates that this is not an accurate claim.

\section{Neonicotinoid Insecticides}

Neonicotinoids are third-generation broad spectrum pesticides intended for the control of sucking (e.g., aphids, whiteflies, leaf- and planthoppers, and thrips) and chewing pest insects (e.g., microlepidoptera and some Coleoptera) $[123,186]$. These pesticides can be translocated to different tissues as a systemic property of this type of pesticide; for instance, neonicotinoids can be absorbed by roots [41,187]. Neonicotinoids can also be applied by directly impregnating treated seeds, a method that transfers a great portion of the pesticides to the soil due to their high solubility in water [188]. The apparent benefits of neonicotinoid applications on plants have been overshadowed by recent studies showing that the use of thiamethoxam (hereafter "TMX") and imidacloprid (hereafter "IMI") on crop sunflowers Helianthus annuus L. (Asteraceae) induces mitotic phase irregularities as 
well as genotoxic effects (e.g., DNA damage and genome instability) [189]. Neonicotinoid pesticides have also been used in home gardens to control domestic pests and in cats and dogs to prevent fleas and ticks [190].

The most common active ingredients in neonicotinoids are IMI, acetamiprid, nitenpyram, TMX, thiacloprid, clothianidin (hereafter "CTD"), and dinotefuran [186]. However, novel formulations are continuously being produced. Neonicotinoid pesticides work by binding to the nicotine acetylcholine receptor (nAChR), thereby affecting the central nervous system of insects $[118,190,191]$. As acetylcholine receptors were proposed as less important for vertebrates than invertebrates, neonicotinoids as pesticides were promoted to be safer for non-target organisms (such as humans) [187]. These ideas have promoted an indiscriminate use of these pesticides in all types of crops and soils, even though the human health impacts of exposure to these chemicals is not fully understood [187].

Often, pesticide application methods, both agricultural and domiciliary, do not appropriately discriminate between target and non-target organisms. Neonicotinoids are not an exception to this problem [192-194]; many different organisms (e.g., insects) may be affected by these toxicants, triggering varied responses [44,195,196]. Neonicotinoid contamination of non-target organisms has been extensively documented in animals [197-199]. For example, neonicotinoid contamination can impact native fauna such as the Japanese crested ibis, where exposure to CTD was found to be detrimental to reproduction, most likely due to triggering oxidative stress [197]. IMI can alter early development in mammals (e.g., mice). These alterations were found to be related to C5-cytosine methylation due to exposure to this neonicotinoid pesticide [200]. Exposure to acetamiprid has been found to be linked to DNAm in rat brain and liver [201]. There have been studies in mice showing that neonicotinoid and acetamiprid can cross the blood-brain barrier, which highlights the severity of the potential risks to mammals [166]. Thus, neonicotinoids trigger alterations in different regulatory process, including EMMs, in vertebrates.

Varied sub-lethal detrimental effects and epigenetic consequences have been also found in other life forms. It has been demonstrated that neonicotinoids are extremely toxic to a great diversity of invertebrates. For instance, the evaluation of the impact of the IMIcontaining insecticide "Tree and Shrub"TM on wildtype Caenorhabditis elegans (Maupas, 1900) (Nematoda: Rhabditidae) disrupted fertility along with growth and locomotion [202]. It has been demonstrated in Gastropoda that neonicotinoid thiacloprid damages the central nervous system of the native species Lymnaea stagnalis (Linnaeus, 1758) (Hygrophila: Lymnaeidae), the great pond snail, through its modulation of nicotinergic acetylcholine receptors, hampering cholinergic neurotransmission [203].

Neonicotinoids lead to death and to a wide array of critical sub-lethal impacts in Insecta evaluated in field-realistic exposure, including alterations linked to EMMs (both in managed and wild species) $[43,119,137,158,204]$. These consequences led to the loss of the ecosystem services provided by these insects, including nutrient cycling and pollination [205]. These declines in local insect biodiversity have been shown to be linked to unexpected costs in agricultural production under industrialized management and impacts on the health of managed agroecosystems [206]. Although non-target insects may be exposed to lower doses of insecticides than target ones, for flying insects, this situation depends also on chance, unless they exhibit behavioral resistance [45]. Exposure to lower doses might not kill them, but there is recent evidence of their impact on different regulatory processes at different scales [140], including providing the descendants with resistance to this pesticide $[83,207]$ and increasing their population via hormetic response [182,208]. In insects, this has been chiefly studied in managed bees Apis mellifera (Linnaeus, 1758) [187]. Nonetheless, there is also a growing body of evidence demonstrating adverse consequences on other managed as well as native insects [209-211].

For instance, in the parasitic wasps key for biological control in agricultural management such as Nasonia vitripennis (Walker, 1836) (Hymenoptera: Pteromalidae), the neonicotinoid imidacloprid disrupts sex allocation cues, reducing their reproductive success [212]. Sub-lethal IMI exposure in the Colorado potato beetle, pest Leptinotarsa decemlineata Say, 
1824 (Coleoptera: Chrysomelidae) has been linked to alterations in specific genes, C5cytosine methylation, and transposable elements that have been postulated as linked to the development of insecticide resistance [81].

Similar patterns were found for one of the major pests of fruit orchards: the codling moth Cydia pomonella (Linnaeus, 1758) (Lepidoptera: Tortricidae). In this pest species, it was found that acetamiprid exposure in a field population triggered a significant increase in biotransformation and antioxidant enzyme activity; the detoxification of acetamiprid was proposed to be achieved by methylation [213]. These hormesis-like resistance patterns were proposed by the authors to be linked with epigenetic mechanisms $[213,214]$.

These consequences on insect biology of the exposure to these toxicants are very likely to be shared between most studied insects (e.g., managed species and model insects) and native insects. For instance, EMMs found to be involved in alterations detected in managed bees due to the application of neonicotinoid pesticides may also impact wild bee species and other native insect species, especially in agricultural landscapes [215]. These plausible scenarios are discussed in the following section, with a particular focus on bees.

\section{Neonicotinoid Effects on Bees}

There is an abundant body of evidence that shows that sub-lethal doses of neonicotinoids have direct effects on several vital functions of Apis mellifera $[41,48,83,120,187,216]$, from reproductive ability to cognitive impairments. These issues have been linked to epigenetic mechanisms [45]. For instance, different authors have described changes in histone acetylation and deacetylation [120,215], their transgenerational inheritance [76], and C5-cytosine methylation effects [41].

There has been strong evidence for almost a whole decade on the involvement of sub-lethal doses of neonicotinoids in the development of colony collapse disorder (hereafter "CCD"). Of particular interest is an experiment showing that the use of highfructose corn syrup (HFCS) as an alternative to honey or sucrose-based food was related to CCD [48]. When the authors investigated the composition of the HFCS used, they found sub-lethal dosages of imidacloprid, a neonicotinoid insecticide widely used in the Americas (Canada, the United States, the Caribbean, and Central and South American countries) and China $[119,190,207,217,218]$. As previously mentioned, imidacloprid and other neonicotinoids are systemic pesticides applied directly to seeds through impregnation, which stay on the plant during its development and are detected in most plant tissues [187], and might end up in the final product that humans and other animals consume, although in much lower concentrations than the original dose [219].

The effects of neonicotinoids on bees are many and wide-ranging (e.g., [137]), including decreased microglomerular density of mushroom bodies [220], symptoms of neurotoxicity [191], reduced fecundity in queens and males [41], and impaired immune response [221], among other issues that challenge the sustainability and survival of colonies [43]. Memory issues in bees have being linked to epigenetic changes, specifically in relation to histone acetylation [120] and DNAm [222]. There is also evidence that exposure to neonicotinoids has global DNA methylation effects on honeybees [119].

Evidence suggests that CCD is related to the emergence of neonicotinoids and their massive use in agriculture [120]. This would be mainly due to the previously described sub-lethal effects of pesticides $[41,43,221]$, which impair the proper functioning of colonies, leading to their ultimate collapse $[48,216,220,223]$.

Ongoing studies are being conducted to understand how to counteract the detrimental effects of neonicotinoids, with sodium butyrate as a possible candidate antidote to the epigenetic modifications experienced by bees exposed to neonicotinoids [120,216]. This kind of research is of high importance due to the menace that declining numbers of bees and other flying insects represent for all kinds of ecosystems and for human survival $[15,224]$. Despite all of these problems detected in different non-target organisms, the use of neonicotinoids is currently poorly regulated, especially in developing countries [205]. 


\section{The Link between Insect EMMs and Current Loss of Biodiversity}

Organisms around the globe are currently experiencing emerging pressures that threaten their survival and are causing the extinction of an unprecedented number of species in a short span of time [28,30]. Insects are being seriously affected by these pressures and their numbers are declining quickly [15], while we can hardly quantify the losses due to the incompleteness of the available information [176].

The main drivers of the global environmental crisis have been classified as "planetary boundaries" or safe operational limits within which the perpetuation of humanity is feasible [225]. Global biodiversity decline is one of the most worrisome limits [224]. The loss of biodiversity has been linked to other planetary boundaries such as climate change, pollution, alteration of biogeochemical cycles, and habitat loss and degradation [45,89]. This last means that habitat quality decrease, for instance, due to fragmentation (i.e., increasing habitat isolation) [29]. These drivers are deeply interdependent and are the main reasons behind the visible reduction in biodiversity that affects our planet. Their interactions and effects are of utmost scientific interest, since most species are threatened by a combination of these and other planetary boundaries instead of the alteration of a single one [224].

The increased weather volatility brought about by climate change [226] and its effects are now felt in a wide variety of ecosystems $[31,227,228]$. There is evidence from previous extinction events that high-frequency fluctuations in mean temperatures and even in geological timescales may elevate the extinction rate in marine invertebrates compared with more stable periods [229]. Thus, the effects of climate change and increasing temperatures in both the upper and deep ocean [230] might have catastrophic results not only for marine biodiversity but also on terrestrial processes highly dependent on its stability [225].

Pollution directly decimates biodiversity not only due to its toxic effects on living organisms but also through the contamination of non-renewable natural resources such as soil and water. Pollution derived from the human productive industry has been stressed as the base of biodiversity loss $[174,231]$. These alterations are also linked to the dramatic alteration of biogeochemical cycles, mostly mediated by soil microorganisms and associated invertebrates [225]. Contamination leads to habitat loss, which is closely related to anthropogenic activities such as intensive agriculture, urban development, and other extractive activities that humans perform in order to thrive under the current economic paradigm [232]. Pesticides are an important factor in habitat loss, which affects the biology of non-target organisms $[83,93,98,111,117,122]$ and/or behavior $[105,116,127,233]$, with potentially lethal consequences $[107,108,114]$.

Habitat fragmentation is caused by a wide array of anthropogenic activities such as intensive agricultural practices [29], with monocultures in huge portions of land affecting whole ecosystems [234], the process of urbanization $[235,236]$ with the building of roads to connect cities that slash through habitats [237-239], and land and sea exploitation for the extraction of fossil fuels or minerals [240,241].

The decrease in habitat quality is deeply linked to the contamination derived from human activities $[242,243]$ such as soil degradation by intensive agriculture and subsequent land abandonment [244,245]; extensive use of fertilizers and the associated nitrogen accumulation [29]; indiscriminate application of pesticides with direct and indirect effects on trophic chains $[122,178,180,246]$; pollution of soil [151,247], and nearby water bodies and streams $[93,98,124,188]$; road building $[237,238]$; and inappropriate management of protected habitats [248].

The abovementioned drivers affect the resilience of the different ecosystems that are exposed to them, reducing the chances of recovery of biodiversity and its functional relations [29]. Different organisms react in a wide array of ways in response to these drivers. While some organisms perish, others are able to adapt through different strategies, which include EMMs $[80,249]$. In fact, EMMs may be key to the survival of entire species because they allow for fast responses to a changing environment, which may be fundamental for the survival of organisms $[80,250]$. 
As shown in Table 2, many studies have been performed in artificial $[84,89,101,125]$ and natural $[91,94,122]$ aquatic settings to emulate scenarios of water pollution. This kind of study is vital in order to gauge the impact of the presence and application of chemicals in the environmEntomol. Since aquatic insects are routinely used as bioindicators of the toxicity of different chemicals [98], it is not surprising that interest in their epigenetic responses to harmful stimuli has grown recently $[11,84,85]$.

As previously mentioned, the response of an insect to pesticide exposure depends on the amount of chemical involved $[83,134]$. The chemical behavior of pesticides in the environment as well as their inaccurate application often lead to the development of resistance in target organisms or even to hormetic responses [115,116,208]. These adaptive mechanisms include epigenetic changes that allow organisms to modify biological processes via changes in gene expression [83]. It has been proposed that new formulations of pesticides should consider their potential epigenetic effects in order to increase their effectiveness and to reduce the damage to non-target species $[44,45,80]$. The use of insect EMMs has also been proposed as a promising venue for the development of methods to ameliorate the negative effects of pesticides once considered "safe". One example of this approach is the application of histone deacetylase inhibition treatment in order to restore learning abilities in honey bees with memory impairment caused by neonicotinoid exposure [120].

While the effects of pesticides on non-target organisms have been widely studied [148], to our knowledge, a direct comparison between a native versus an introduced species in order to assess whether there are differences in their responses towards a specific pesticide has not been made (Table 2). A few studies have been conducted in bees [251] and ants [252]. In these evaluations, contrasts have been shown on how pesticides affect native and introduced species, suggesting that while native species suffer mostly detrimental effects, pests are capable of developing resistance with sub-lethal exposures. These trends stress the need for further research on this subject, especially the relation between pesticides and EMMs, as these links may hold the key for these contrasting responses to stress derived from agrochemicals. This would allow for better understanding of the potential damage that pesticides may inflict in ecosystems and helps manufacturers produce more precise pesticides that inflict less environmental damage [253].

We must reiterate the importance of investigating EMMs involved in the responses of insects towards pesticide exposure. As shown in Table 1, to the best of our knowledge, there are at least three main processes described as EMMs. Thus far, insect EMMs triggered in relation to the exposure of environmental toxicants are mainly DNAm and RNA-based mechanisms, while in vertebrates, it has been shown that histone alterations can also be triggered due to pesticide exposure. This has been found in rats exposed to the pesticide Dichlorodiphenyltrichloroethane, DDT [254]. These differences may be due to the nature of these particular EMMs and the biases towards the study of vertebrates as a proxy for human health. Nonetheless, considering that the abovementioned evidences showing that histone deacetylase inhibitors are capable of upregulating memory-related genes in IMI memory-damaged bees [119], it is possible to suggest a key role of post-translational processes in relation to insect epigenetic responses facing the exposure to toxicant stress. Despite this, it is also probable that there is a lack of studies on other species besides canonical model organisms and ecological contexts involved in insect epigenetic responses towards toxicants. This scenario emphasizes the need for further research on this topic both from applied and basic points of view.

The actual complexity of the relationship between inheritance, environmental cues, and their phenotypic consequences found in different systems (including insects) allows us to recognize that EMMs contribute to the systemic regulation and stabilization properties of living organisms [255]. Understanding the biological mechanisms involved in insect epigenetic responses towards agrochemicals, what stage of insect ontogeny it affects, and what type of disturbances or compensations are triggered in its features is fundamental to assessing the impact of pesticides in insects (native, managed, and pest species). This may 
hold the key to reducing the damage of pesticides to non-target species and thus helps in the fight against the current global decline in biodiversity [45,83].

\section{Conclusions}

In a rapidly changing world with several planetary boundaries near collapse [225], the consideration of the role of EMMs in the context of insect exposure to variated and abundant human-derived stressors (such as pesticides) may be relevant to prevent further population declines in wild insect species. This understanding also helps to prevent the development of pesticide resistance in pests and introduced species that should be controlled [83]. Intensified schemes of agricultural production have been shown to be the main contributors to biodiversity decline globally, including the demise of pollinating insects [256-259]. In particular, pesticide use is one of the main factors responsible for the decimation of managed as well as native pollinators $[135,157,260]$.

By studying insect EMMs in response to stressors both in the wild and in agriculturally managed ecosystems, it becomes possible to understand why some species can adapt rapidly while others perish. As we have shown here, there is strong evidence that supports the thesis that responses involving EMMs should be considered in the formulation and testing of new pesticides as well as in the search for more sustainable and ecologically minded alternatives. These new developments may be fundamental to understanding the biological responses of affected organisms to control measures and may provide tools to avoid formulations that have proven detrimental effects on ecosystems [44,45,80]. New knowledge and technology developed based on EMMs in insects may allow us to find ways to ameliorate the consequences of pollinator exposure to pesticides. Promising results have been shown in honeybee memory repair through treatments involving EMMs [120]. A better understanding of EMMs in insects could be an important resource in the fight against the loss of biodiversity that we currently face in what has been called the sixth mass extinction $[28,32,240,261]$.

\section{Further Remarks}

The epigenetic effects found in insects due to pesticide exposure should be "the canary in the coal mine" for the consequences of contamination on our own species and a source of development for novel technologies to allow us to have a more sustainable relationship with biodiversity. The chemical behavior of different pesticides demonstrates that it is almost impossible to control the contamination of soil and water sources, and the exposure of nontarget organisms to the current toxic formulations $[161,165,171]$. This pollution may affect vulnerable native and endemic species, where EMMs are found to be associated with stress and abnormal functioning in insects. To worsen the situation, among non-target organisms, it is possible to find undesired pest and invasive insects, where EMMs lead to the development of tolerance and resistance against pesticides. There is evidence for the role of EMMs in the development of resistance towards pesticides. This has been demonstrated in insects with aquatic immature stages such as mosquitoes [11].

Thus, a change towards a better understanding of insect epigenetics as well as the application of agroecological approaches promoting sustainable agriculture is a must $[54,205,262])$. Future evidence of EMM-related changes in insects exposed to pesticides may serve as bioindicators of potentially dangerous levels of exposure to contamination in our own species. This is another promising venue of research in relation to EMMs in insects and their effects in response to anthropogenically derived contamination.

Author Contributions: Conceptualization, G.O.-C., C.V. and C.G.-B.; methodology, G.O.-C. and C.V.; validation, C.V. and C.G.-B.; investigation, G.O.-C.; data curation, G.O.-C., C.V., C.G.-B. and L.C.-J.; writing-original draft preparation, G.O.-C., L.C.-J. and C.G.-B.; writing-review and editing, G.O.-C., L.C.-J. and C.G.-B.; visualization, G.O.-C.; supervision, C.V. and C.G.-B. All authors have read and agreed to the published version of the manuscript. 
Funding: Publishing costs were partially provided by DIP-UMCE 2021. C. G-B. greatly appreciate funding from the Swedish Research Council for Environment, Agricultural Sciences and Spacial Planning (FORMAS) grant \#2018-01074.

Institutional Review Board Statement: Not applicable.

Informed Consent Statement: Not applicable.

Data Availability Statement: All data are presented in the manuscript.

Acknowledgments: We are grateful to Lafayette Eaton for reviewing the English and for the enriching comments on our work. We also thanks Joaquín Ossandón for insightful comments on our manuscript.

Conflicts of Interest: The authors declare no conflict of interest.

\section{References}

1. Burggren, W. Epigenetic Inheritance and its Role in Evolutionary Biology: Re-evaluation and New Perspectives. Biology 2016, 5, 24. [CrossRef] [PubMed]

2. Mukherjee, K.; Twyman, R.M.; Vilcinskas, A. Insects as Models to Study the Epigenetic Basis of Disease. Prog. Biophys. Mol. Biol. 2015, 118, 69-78. [CrossRef] [PubMed]

3. Ware, G.W. Effects of Pesticides on Nontarget Organisms. In Residue Reviews; Springer: New York, NY, USA, 1980 ; pp. $173-201$.

4. Bird, A. Perceptions of Epigenetics. Nature 2007, 447, 396. [CrossRef]

5. Jablonka, E.; Lamb, M.J. Evolution in Four Dimensions: Genetic, Epigenetic, Behavioral, and Symbolic Variation in the History of Life, 1st ed.; MIT Press: Cambridge, MA, USA, 2005; Volume 5.

6. Jaenisch, R.; Bird, A. Epigenetic Regulation of Gene Expression: How the Genome Integrates Intrinsic and Environmental signals. Nat. Gen. 2003, 33, 245. [CrossRef]

7. Glastad, K.M.; Hunt, B.G.; Goodisman, M.A. Epigenetics in Insects: Genome Regulation and the Generation of Phenotypic Diversity. Ann. Rev. Entomol. 2019, 64, 185-203. [CrossRef]

8. Berens, A.J.; Hunt, J.H.; Toth, A.L. Nourishment Level Affects Caste-related Gene Expression in Polistes wasps. BMC Gen. 2015, 16, 1-2. [CrossRef]

9. Patalano, S.; Hore, T.A.; Reik, W.; Sumner, S. Shifting Behaviour: Epigenetic Reprogramming in Eusocial Insects. Curr. Opin. Cell Biol. 2012, 24, 367-373. [CrossRef]

10. Kavi, L.A.; Kaufman, P.E.; Scott, J.G. Genetics and Mechanisms of Imidacloprid Resistance in House flies. Pest. Biochem. Physiol. 2014, 109, 64-69. [CrossRef]

11. Oppold, A.; Kress, A.; Bussche, J.V.; Diogo, J.B.; Kuch, U.; Oehlmann, J.; Vandegehuchte, M.B.; Müller, R. Epigenetic Alterations and Decreasing Insecticide Sensitivity of the Asian Tiger Mosquito Aedes albopictus. EcoToxicol. Environ. Saf. 2015, 122, 45-53. [CrossRef]

12. Feldhaar, H.; Otti, O. Pollutants and Their Interaction with Diseases of Social Hymenoptera. Insects 2020, 11, 153. [CrossRef]

13. Ardura, A.; Clusa, L.; Zaiko, A.; Garcia-Vazquez, E.; Miralles, L. Stress Related Epigenetic Changes May Explain Opportunistic Success in Biological Invasions in Antipode mussels. Sci. Rep. 2018, 8, 1-10. [CrossRef]

14. Hallmann, C.A.; Sorg, M.; Jongejans, E.; Siepel, H.; Hofland, N.; Schwan, H.; Stenmans, W.; Müller, A.; Sumser, H.; Hörren, T.; et al. More than 75 Percent Decline Over 27 Years in Total Flying Insect Biomass in Protected Areas. PLoS ONE 2017, 12, e0185809. [CrossRef] [PubMed]

15. Cardoso, P.; Barton, P.S.; Birkhofer, K.; Chichorro, F.; Deacon, C.; Fartmann, T.; Fukushima, C.S.; Gaigher, R.; Habel, J.C.; Hallmann, C.A.; et al. Scientists' Warning to Humanity on Insect Extinctions. Biol. Conserv. 2020, 242, 108426. [CrossRef]

16. Van der Sluijs, J.P. Insect Decline, an Emerging Global Environmental Risk. Curr. Opin. Environ. Sustain. 2020, 46, 39-42. [CrossRef]

17. Pearson, M.M. Phase Variation of the mrp Fimbrial Promoter. In Proteus mirabilis; Humana: New York, NY, USA, 2019; pp. 121-127.

18. Frandi, A.; Collier, J. Multilayered Control of Chromosome Replication in Caulobacter crescentus. Biochem. Soc. Trans. 2019, 47, 187-196. [CrossRef] [PubMed]

19. Skinner, M.K.; Nilsson, E.; Sadler-Riggleman, I.; Beck, D.; Ben Maamar, M.; McCarrey, J.R. Transgenerational Sperm DNA Methylation Epimutation Developmental Origins Following Ancestral Vinclozolin Exposure. Epigenetics 2019, 14, 721-739. [CrossRef]

20. House, M.; Lukens, L. The Role of Germinally Inherited Epialleles in Plant Breeding: An Update. In Epigenetics in Plants of Agronomic Importance: Fundamentals and Applications; Springer: Cham, Switzerland, 2019; pp. 115-128.

21. Tucci, V.; Isles, A.R.; Kelsey, G.; Ferguson-Smith, A.C.; Erice Imprinting Group. Genomic Imprinting and Physiological Processes in Mammals. Cell 2019, 176, 952-965. [CrossRef]

22. Di Felice, F.; Egidi, A.; D'Alfonso, A.; Camilloni, G. Fob1p recruits DNA Topoisomerase I to Ribosomal Genes Locus and Contributes to its Transcriptional Silencing Maintenance. Int. J. Biochem. Cell Biol. 2019, 110, 143-148. [CrossRef] [PubMed] 
23. Żylicz, J.J.; Bousard, A.; Žumer, K.; Dossin, F.; Mohammad, E.; da Rocha, S.T.; Schwalb, B.; Syx, L.; Dingli, F.; Loew, D.; et al. The Implication of Early Chromatin Changes in X Chromosome Inactivation. Cell 2019, 176, 182-197. [CrossRef]

24. Shevchenko, A.I.; Dementyeva, E.V.; Zakharova, I.S.; Zakian, S.M. Diverse Developmental Strategies of X Chromosome Dosage Compensation in Eutherian Mammals. Int. J. Dev. Biol. 2019, 63, 223-233. [CrossRef]

25. Zhong, P.; Li, J.; Luo, L.; Zhao, Z.; Tian, Z. TOP1 $\alpha$ Regulates FLOWERING LOCUS C Expression by Coupling Histone Modification and Transcription Machinery. Development 2019, 146, 4. [CrossRef]

26. Posner, R.; Toker, I.A.; Antonova, O.; Star, E.; Anava, S.; Azmon, E.; Hendricks, M.; Bracha, S.; Gingold, H.; Rechavi, O. Neuronal Small RNAs Control Behavior Transgenerationally. Cell 2019, 177, 1814-1826. [CrossRef]

27. Dupont, C.; Kappeler, L.; Saget, S.; Grandjean, V.; Lévy, R. Role of miRNA in the Transmission of Metabolic Diseases Associated with Paternal Diet-induced Obesity. Front. Gen. 2019, 10, 337. [CrossRef]

28. Ceballos, G.; Ehrlich, P.R.; Raven, P.H. Vertebrates on the Brink s Indicators of Biological Annihilation and the Sixth Mass Extinction. Proc. Natl. Acad. Sci. USA 2020, 117, 13596-13602. [CrossRef]

29. Habel, J.C.; Samways, M.J.; Schmitt, T. Mitigating the Precipitous Decline of Terrestrial European Insects: Requirements for a New Strategy. Biodivers. Conserv. 2019, 28, 1343-1360. [CrossRef]

30. Ceballos, G.; Ehrlich, P.R.; Dirzo, R. Biological Annihilation Via the Ongoing Sixth Mass Extinction Signaled by Vertebrate Population Losses and Declines. Proc. Natl. Acad. Sci. USA 2017, 114, E6089-E6096. [CrossRef] [PubMed]

31. Giersch, J.J.; Hotaling, S.; Kovach, R.P.; Jones, L.A.; Muhlfeld, C.C. Climate-Induced Glacier and Snow Loss Imperils Alpine Stream Insects. Glob. Chang. Biol. 2017, 23, 2577-2589. [CrossRef]

32. Barnosky, A.D.; Matzke, N.; Tomiya, S.; Wogan, G.O.; Swartz, B.; Quental, T.B.; Marshall, C.; McGuire, J.L.; Lindsey, E.L.; Maguire, K.C.; et al. Has the Earth's Sixth Mass Extinction Already Arrived? Nature 2011, 471, 51-57. [CrossRef]

33. Kim, K.C. Biodiversity, Conservation and Inventory: Why Insects Matter. Biodivers. Conserv. 1993, 2, 191-214. [CrossRef]

34. Hamilton, C.; Gemenne, F.; Bonneuil, C. Thinking the anthropocene. In The Anthropocene and The Global Environmental Crisis: Rethinking Modernity In A New Epoch, 1st ed.; Hamilton, C., Bonneuil, C., Gemenne, F., Eds.; Routledge: Abingdon, UK, 2015; pp. 1-13.

35. Rusiecki, J.A.; Beane Freeman, L.E.; Bonner, M.R.; Alexander, M.; Chen, L.; Andreotti, G.; Barry, K.H.; Moore, L.E.; Byun, H.M.; Kamel, F.; et al. High Pesticide Exposure Events and DNA Methylation Among Pesticide Applicators in The Agricultural Health Study. Environ. Mol. Mutagenesis 2017, 58, 19-29. [CrossRef]

36. Morais, S.; Dias, E.; Pereira, M.L. Carbamates: Human exposure and health effects. In The Impact of Pesticides; Academy Publication: London, UK, 2012; pp. 21-38.

37. Requena-Mullor, M.; Navarro-Mena, A.; Wei, R.; López-Guarnido, O.; Lozano-Paniagua, D.; Alarcon-Rodriguez, R. Evaluation of Gonadal Alterations in a Population Environmentally Exposed to a Mixture of Endocrine Active Pesticides. Int. J. Environ. Res. Public Health 2021, 18, 2355. [CrossRef]

38. Ekroos, J.; Kleijn, D.; Batáry, P.; Albrecht, M.; Báldi, A.; Blüthgen, N.; Knop, E.; Kovács-Hostyánszki, A.; Smith, H.G. High Land-use Intensity in Grasslands Constrains Wild Bee Species Richness in Europe. Biol. Conserv. 2020, 241, 108255. [CrossRef]

39. Gallai, N.; Salles, J.M.; Settele, J.; Vaissière, B.E. Economic Valuation of the Vulnerability of World Agriculture Confronted with Pollinator Decline. Ecol. Econ. 2009, 68, 810-821. [CrossRef]

40. Xider, K.M. Histopathological and Morphological Alterations in Salivary Gland of House Fly Induced by Oral Administration Thiamethoxam. Kurd. J. Appl. Res. 2018, 3, 40-44. [CrossRef]

41. Bebane, P.S.; Hunt, B.J.; Pegoraro, M.; Jones, A.C.; Marshall, H.; Rosato, E.; Mallon, E.B. The Effects of the Neonicotinoid Imidacloprid on Gene Expression and DNA Methylation in the Buff-Tailed Bumblebee Bombus terrestris. Proc. R. Soc. B Biol. Sci. 2019, 286, 20190718. [CrossRef] [PubMed]

42. Mao, W.; Schuler, M.A.; Berenbaum, M.R. Honey Constituents Up-Regulate Detoxification and Immunity Genes in The Western Honey Bee Apis mellifera. Proc. Natl. Acad. Sci. USA 2013, 110, 8842-8846. [CrossRef]

43. Pisa, L.W.; Amaral-Rogers, V.; Belzunces, L.P.; Bonmatin, J.M.; Downs, C.A.; Goulson, D.; Kreutzweiser, D.P.; Krupke, C.; Liess, M.; McField, M.; et al. Effects of Neonicotinoids and Fipronil on Non-Target Invertebrates. Environ. Sci. Pollut. Res. 2015, 22, 68-102. [CrossRef]

44. Brevik, K.; Lindström, L.; McKay, S.D.; Chen, Y.H. Transgenerational Effects of Insecticides-Implications for Rapid Pest Evolution in Agroecosystems. Curr. Opin. Insect Sci. 2018, 26, 34-40. [CrossRef] [PubMed]

45. Oppold, A.M.; Müller, R. Epigenetics: A hidden target of insecticides. Adv. Insect Phys. 2017, 53, 313-324.

46. Gressel, J. Evolving Understanding of The Evolution of Herbicide Resistance. Pest Man. Sci. 2009, 65, 1164-1173. [CrossRef]

47. Chiron, F.; Chargé, R.; Julliard, R.; Jiguet, F.; Muratet, A. Pesticide Doses, Landscape Structure and their Relative Effects on Farmland Birds. Agric. Ecosyst. Environ. 2014, 185, 153-160. [CrossRef]

48. Chensheng, L.U.; Warchol, K.M.; Callahan, R.A. In Situ Replication of Honey Bee Colony Collapse Disorder. Bull. Insect 2012, 65, 99-106.

49. Burdge, G.C.; Lillycrop, K.A. Nutrition, Epigenetics, and Developmental Plasticity: Implications for Understanding Human Disease. Ann. Rev. Nutr. 2010, 30, 315-339. [CrossRef]

50. Feil, R.; Fraga, M.F. Epigenetics and The Environment: Emerging Patterns and Implications. Nat. Rev. Gen. 2012, 13, 97-109. [CrossRef] [PubMed] 
51. Laubach, Z.M.; Perng, W.; Dolinoy, D.C.; Faulk, C.D.; Holekamp, K.E.; Getty, T. Epigenetics and the Maintenance of Developmental Plasticity: Extending the Signalling Theory Framework. Biol. Rev. 2018, 93, 1323-1338. [CrossRef] [PubMed]

52. Vidaki, A.; Daniel, B.; Court, D.S. Forensic DNA Methylation Profiling-Potential Opportunities and Challenges. Forensic Sci. Int. Gen. 2013, 7, 499-507. [CrossRef]

53. Hunt, B.G.; Glastad, K.M.; Yi, S.V.; Goodisman, M.A. The Function of Intragenic DNA Methylation: Insights From Insect Epigenomes. Integr. Comp. Biol. 2013, 53, 319-328. [CrossRef]

54. Villagra, C.; Frías-Lasserre, D. Epigenetic Molecular Mechanisms in Insects. Neot. Entomol. 2020, 49, 615-642. [CrossRef]

55. Kim, D.; Thairu, M.W.; Hansen, A.K. Novel Insights Into Insect-Microbe Interactions-Role of Epigenomics and Small Rnas. Front. Plant Sci. 2016, 7, 1164. [CrossRef]

56. Jia, G.; Fu, Y.; Zhao, X.; Dai, Q.; Zheng, G.; Yang, Y.; Yi, C.; Lindahl, T.; Pan, T.; Yang, Y.G.; et al. N 6-Methyladenosine in Nuclear RNA is a Major Substrate of the Obesity-Associated FTO. Nat. Chem. Biol. 2011, 7, 885-887. [CrossRef] [PubMed]

57. Mattick, J.S.; Amaral, P.P.; Dinger, M.E.; Mercer, T.R.; Mehler, M.F. RNA Regulation of Epigenetic Processes. Bioessays 2009, 31, 51-59. [CrossRef]

58. Bushati, N.; Cohen, S.M. microRNA Functions. Ann. Rev. Cell Dev. Biol. 2007, 23, 175-205. [CrossRef]

59. Morales-Nebreda, L.; McLafferty, F.S.; Singer, B.D. DNA Methylation as a Transcriptional Regulator of the Immune System. Transl. Res. 2019, 204, 1-8. [CrossRef]

60. Alavian-Ghavanini, A.; Rüegg, J. Understanding Epigenetic Effects of Endocrine Disrupting Chemicals: From Mechanisms to Novel Test Methods. Basic Clin. Pharmacol. Toxicol. 2018, 122, 38-45. [CrossRef] [PubMed]

61. Modified Histone Antibodies. Available online: https://www.cusabio.com/catalog-67-1.html (accessed on 12 July 2020 ).

62. Koch, M.W.; Metz, L.M.; Kovalchuk, O. Epigenetics and Mirnas in the Diagnosis and Treatment of Multiple Sclerosis. Trends Mol. Med. 2013, 19, 23-30. [CrossRef]

63. Bernstein, B.E.; Meissner, A.; Lander, E.S. The Mammalian Epigenome. Cell 2007, 128, 669-681. [CrossRef]

64. Faulk, C.; Dolinoy, D.C. Timing is Everything: The When and How of Environmentally Induced Changes in the Epigenome of Animals. Epigenetics 2011, 6, 791-797. [CrossRef]

65. Burggren, W.W. Epigenetics in Insects: Mechanisms, Phenotypes and Ecological and Evolutionary Implications. Adv. Insect Phys. 2017, 53, 1-30.

66. Kozeretska, I.A.; Serga, S.V.; Koliada, A.K.; Vaiserman, A.M. Epigenetic Regulation of Longevity in Insects. Adv. Insect Phys. 2017, $53,87-114$.

67. Youngson, N.A.; Whitelaw, E. Transgenerational Epigenetic Effects. Ann. Rev. Gen. Hum. Gen. 2008, 9, 233-257. [CrossRef] [PubMed]

68. Tikhodeyev, O.N. The Mechanisms of Epigenetic Inheritance: How Diverse Are They? Biol. Rev. 2018, 93, 1987-2005. [CrossRef]

69. Wang, H.; Liu, Z.; Wang, Y.; Ma, L.; Zhang, W.; Xu, B. Genome-Wide Differential DNA Methylation in Reproductive, Morphological, and Visual System Differences Between Queen Bee and Worker Bee (Apis mellifera). Front. Gen. 2020, 11, 770. [CrossRef]

70. Gulati, P.; Kohli, S.; Narang, A.; Brahmachari, V. A Comparative Analysis of Histone Methyltransferases and Demethylases in Insect Genome: A Meta-Analysis. bioRxiv 2019, 598946. [CrossRef]

71. Mukherjee, K.; Dubovskiy, I.; Grizanova, E.; Lehmann, R.; Vilcinskas, A. Epigenetic Mechanisms Mediate the Experimental Evolution of Resistance Against Parasitic Fungi in the Greater Wax Moth Galleria mellonella. Sci. Rep. 2019, 9, 1-11. [CrossRef] [PubMed]

72. Ney, G.; Schul, J. Epigenetic and Genetic Variation Between Two Behaviorally Isolated Species of Neoconocephalus (Orthoptera: Tettigonioidea). J. Orthoptera Res. 2019, 28, 11. [CrossRef]

73. Lo, N.; Simpson, S.J.; Sword, G.A. Epigenetics and Developmental Plasticity in Orthopteroid Insects. Curr. Opin. Insect Sci. 2018, 25, 25-34. [CrossRef]

74. Reynolds, J.A.; Clark, J.; Diakoff, S.J.; Denlinger, D.L. Transcriptional Evidence for Small RNA Regulation of Pupal Diapause in the Flesh Fly, Sarcophaga bullata. Insect Biochem. Mol. Biol. 2013, 43, 982-989. [CrossRef]

75. Khosla, S.; Mendiratta, G.; Brahmachari, V. Genomic Imprinting in the Mealybugs. Cytogen. Gen. Res. 2006, 113, 41-52. [CrossRef]

76. Morandin, C.; Brendel, V.P.; Sundström, L.; Helanterä, H.; Mikheyev, A.S. Changes in Gene DNA Methylation and Expression Networks Accompany Caste Specialization and Age-Related Physiological Changes in a Social Insect. Mol. Ecol. 2019, 28, 1975-1993. [CrossRef]

77. Simola, D.F.; Graham, R.J.; Brady, C.M.; Enzmann, B.L.; Desplan, C.; Ray, A.; Zwiebel, L.J.; Bonasio, R.; Reinberg, D.; Liebig, J.; et al. Epigenetic (Re) Programming of Caste-Specific Behavior in the Ant Camponotus floridanus. Science 2016, 351, 6268. [CrossRef]

78. Arsenault, S.V.; Hunt, B.G.; Rehan, S.M. The Effect of Maternal Care on Gene Expression and DNA Methylation in a Subsocial Bee. Nat. Commun. 2018, 9, 1-9. [CrossRef]

79. Richard, G.; Le Trionnaire, G.; Danchin, E.; Sentis, A. Epigenetics and Insect Polyphenism: Mechanisms and Climate Change Impacts. Curr. Opin. Insect Sci. 2019, 35, 138-145. [CrossRef]

80. Chatterjee, N.; Gim, J.; Choi, J. Epigenetic Profiling to Environmental Stressors in Model and Non-Model Organisms: Ecotoxicology Perspective. Environ. Health Toxicol. 2018, 33, 3. [CrossRef] [PubMed]

81. Brevik, K.; Bueno, E.M.; McKay, S.; Schoville, S.D.; Chen, Y.H. Insecticide Exposure Affects Intergenerational Patterns of DNA Methylation in the Colorado Potato Beetle, Leptinotarsa decemlineata. Evol. Appl. 2021, 14, 1-12. [CrossRef] 
82. Seebacher, F.; Krause, J. Epigenetics of Social Behaviour. Trends Ecol. Evol. 2019, 34, 818-830. [CrossRef]

83. Bantz, A.; Camon, J.; Froger, J.A.; Goven, D.; Raymond, V. Exposure to Sublethal Doses of Insecticide and their Effects on Insects at Cellular and Physiological Levels. Curr. Opin. Insect Sci. 2018, 30, 73-78. [CrossRef] [PubMed]

84. Jeanrenaud, A.C.; Brooke, B.D.; Oliver, S. Larval Metal Pollutant Exposure Alters the Epigenetic Architecture of the Major Malaria Vector Anopheles arabiensis (Diptera: Culicidae). Res. Sq. 2020. [CrossRef]

85. Planelló, R.; Martínez-Guitarte, J.L.; Morcillo, G. The Endocrine Disruptor Bisphenol a Increases the Expression of HSP70 and Ecdysone Receptor Genes in the Aquatic Larvae of Chironomus riparius. Chemosphere 2008, 7, 1870-1876. [CrossRef]

86. Roelofs, D.; Janssens, T.K.; Timmermans, M.J.; Nota, B.; Marien, J.; Bochdanovits, Z.; Ylstra, B.; Van Straalen, N.M. Adaptive Differences in Gene Expression Associated with Heavy Metal Tolerance in the Soil Arthropod Orchesella cincta. Mol. Ecol. 2009, 18, 3227-3239. [CrossRef]

87. Gintenreiter, S.; Ortel, J.; Nopp, H.J. Effects of Different Dietary Levels of Cadmium, Lead, Copper, and Zinc on the Vitality of the Forest Pest Insect Lymantria dispar L. (Lymantriidae, Lepid). Arch. Environ. Contam. Toxicol. 1993, 25, 62-66. [CrossRef]

88. Dai, T.M.; Lü, Z.C.; Liu, W.X.; Wan, F.H.; Hong, X.Y. The Homology Gene Btdnmt1 is Essential for Temperature Tolerance in Invasive Bemisia Tabaci Mediterranean Cryptic Species. Sci. Rep. 2017, 7, 1-11. [CrossRef]

89. Rayms-Keller, A.; McGaw, M.; Oray, C.; Carlson, J.O.; Beaty, B.J. Molecular Cloning and Characterization of a Metal Responsive Aedes Aegypti Intestinal Mucin Cdna. Insect Mol. Biol. 2000, 9, 419-426. [CrossRef]

90. Raes, H.; Braeckman, B.P.; Criel, G.R.; Rzeznik, U.; Vanfleteren, J.R. Copper Induces Apoptosis in Aedes C6/36 Cells. J. Exp. Zool. 2000, 286, 1-2. [CrossRef]

91. Carlisle, D.M.; Clements, W.H. Growth and Secondary Production of Aquatic Insects Along a Gradient of Zn Contamination in Rocky Mountain Streams. J. N. Am. Benth. Soc. 2003, 22, 582-597. [CrossRef]

92. Wu, Z.; Du, Y.; Xue, H.; Wu, Y.; Zhou, B. Aluminum Induces Neurodegeneration and its Toxicity Arises from Increased Iron Accumulation and Reactive Oxygen Species (ROS) Production. Neurobiol. Aging 2012, 33, 199-e1. [CrossRef]

93. Hitchcock, S.W. Field and Laboratory Studies of DDT And Aquatic Insects; Connecticut Agricultural Experiment Station: New Haven, CT, USA, 1965.

94. Moye, W.C.; Luckmann, W.H. Fluctuations in Populations of Certain Aquatic Insects Following Application of Aldrin Granules to Sugar Creek, Iroquois County, Illinois. J. Econ. Entomol. 1964, 57, 318-322. [CrossRef]

95. Gupta, A.P.; Sutherland, D.J. Effects of Sublethal Doses of Chlordane on the Hemocytes and Midgut Epithelium of Periplaneta americana. Ann. Entomol. Soc. Am. 1968, 61, 910-918. [CrossRef]

96. Wafford, K.A.; Sattelle, D.B.; Gant, D.B.; Eldefrawi, A.T.; Eldefrawi, M.E. Noncompetitive Inhibition of GABA Receptors in Insect and Vertebrate CNS By Endrin and Lindane. Pest. Biochem. Physiol. 1989, 33, 213-219. [CrossRef]

97. Lummis, S.C.; Buckingham, S.D.; Rauh, J.J.; Sattelle, D.B. Blocking Actions of Heptachlor at an Insect Central Nervous System GABA Receptor. Proc. R. Soc. Lond. B 1990, 240, 97-106.

98. Maund, S.J.; Peither, A.; Taylor, E.J.; Jüttner, I.; Beyerle-Pfnür, R.; Lay, J.P.; Pascoe, D. Toxicity of Lindane to Freshwater Insect Larvae in Compartments of an Experimental Pond. EcoToxicol. Environ. Saf. 1992, 23, 76-88. [CrossRef]

99. Matsumura, F.; Hogendijk, C.J. Insect Resistance to Insecticides, Enzymatic Degradation of Parathion in OrganophosphateSusceptible and-Resistant Houseflies. J. Agric. Food Chem. 1964, 12, 447-453. [CrossRef]

100. Krueger, H.R.; O'brien, R.D. Relationship Between Metabolism and Differential Toxicity of Malathion in Insects and Mice. J. Econ Entomol. 1959, 52, 1063-1067. [CrossRef]

101. Magbanua, F.S.; Townsend, C.R.; Hageman, K.J.; Piggott, J.J.; Matthaei, C.D. Individual and Combined Effects of Fine Sediment and Glyphosate Herbicide on Invertebrate Drift and Insect Emergence: A Stream Mesocosm ExperimEntomol. Fresh. Sci. 2016, 35, 139-151. [CrossRef]

102. Hamm, R.L.; Kaufman, P.E.; Reasor, C.A.; Rutz, D.A.; Scott, J.G. Resistance to cyfluthrin and tetrachlorvinphos in the lesser mealworm, Alphitobius diaperinus, collected from the eastern United States. Pest Man. Sci. 2006, 62, 673-677. [CrossRef] [PubMed]

103. Kristensen, M.; Knorr, M.; Spencer, A.G.; Jespersen, J.B. Selection and Reversion of Azamethiphos-Resistance in a Field Population of the Housefly Musca domestica (Diptera: Muscidae), and the Underlying Biochemical Mechanisms. J. Econ. Entomol. 2000, 93, 1788-1795. [CrossRef] [PubMed]

104. Alston, D.G.; Tepedino, V.J.; Bradley, B.A.; Toler, T.R.; Griswold, T.L.; Messinger, S.M. Effects of the Insecticide Phosmet on Solitary Bee Foraging and Nesting in Orchards of Capitol Reef National Park, Utah. Environ. Entomol. 2007, 36, 811-816. [CrossRef] [PubMed]

105. Chernaki-Leffer, A.M.; Sosa-Gómez, D.R.; Almeida, L.M.; Lopes, I.D. Susceptibility of Alphitobius diaperinus (Panzer) (Coleoptera, Tenebrionidae) to Cypermethrin, Dichlorvos and Triflumuron in Southern Brazil. Rev. Bras. Entomol. 2011, 55, 125-128. [CrossRef]

106. Jales, J.T.; de Moura Barbosa, T.; Dos Santos, L.C.; Rachetti, V.D.; Gama, R.A. Carrion Decomposition and Assemblage of Necrophagous Dipterans Associated with Terbufos (Organophosphate) Intoxicated Rat Carcasses. Act. Trop. 2020, $212,105652$. [CrossRef]

107. Eldefrawi, M.E.; Hoskins, W.M. Relation of the Rate of Penetration and Metabolism to the Toxicity of Sevin to Three Insect Species. J. Econ. Entomol. 1961, 54, 401-405. [CrossRef]

108. Davis, J.W.; Cowan, C.B., Jr. Field Evaluation of Three Formulations of Aldicarb for Control of Cotton Insects. J. Econ. Entomol. 1972, 65, 231-232. [CrossRef] 
109. Spurr, H.W., Jr.; Sousa, A.A. Potential Interactions of Aldicarb and its Metabolites on Nontarget Organisms in the EnvironmEntomol. J. Environ. Qual. 1974, 3, 130-133. [CrossRef]

110. Ball, H.J.; Su, P.P. Effect of Sublethal Dosages of Carbofuran and Carbaryl on Fecundity and Longevity of the Female Western Corn Rootworm. J. Econ. Entomol. 1979, 72, 873-876. [CrossRef]

111. Gammon, D.W. Neural Effects of Allethrin on the Free Walking Cockroach Periplaneta americana: An Investigation Using Defined Doses At 15 and 32 C. Pest. Sci. 1978, 9, 79-91. [CrossRef]

112. Dai, P.L.; Wang, Q.; Sun, J.H.; Liu, F.; Wang, X.; Wu, Y.Y.; Zhou, T. Effects of Sublethal Concentrations of Bifenthrin and Deltamethrin on Fecundity, Growth, and Development of the Honeybee Apis mellifera ligustica. Environ. Toxicol. Chem. 2010, 29, 644-649. [CrossRef] [PubMed]

113. Nadda, G.; Saxena, P.N.; Srivastava, G. Effects of Sublethal Doses of Beta-Cyfluthrin on Mutant Drosophila melanogaster (Diptera: Drosophilidae). Appl. Entomol. Zool. 2005, 40, 265-271. [CrossRef]

114. Saha, S.; Kaviraj, A. Acute Toxicity of Synthetic Pyrethroid Cypermethrin to Some Freshwater Organisms. Bull. Environ. Contam. Toxicol. 2008, 80, 49-52. [CrossRef]

115. Schleier, J.J.; Peterson, R.K. Toxicity and Risk of Permethrin and Naled to Non-Target Insects after Adult Mosquito ManagemEntomol. Ecotoxicology 2010, 19, 1140-1146. [CrossRef]

116. Oberhauser, K.S.; Manweiler, S.A.; Lelich, R.; Blank, M.; Batalden, R.V.; De Anda, A. Impacts of Ultra-Low Volume Resmethrin Applications on Non-Target Insects. J. Am. Mosqu. Contr. Assoc. 2009, 25, 83-93. [CrossRef]

117. Britch, S.C.; Linthicum, K.J.; Kline, D.L.; Aldridge, R.L.; Golden, F.V.; Wittie, J.; Henke, J.; Hung, K.; Gutierrez, A.; Snelling, M.; et al. Transfluthrin Spatial Repellent on US Military Materials Reduces Culex tarsalis Incursion in a Desert. Environ. Entomol. J. Am. Mosqu. Contr. Assoc. 2020, 36, 37-42. [CrossRef]

118. Abdel-Haleem, D.R.; Genidy, N.A.; Fahmy, A.R.; Azm, A.E.; Fatma, S.M.; Ismail, N.S. Comparative Modelling, Toxicological and Biochemical Studies of Imidacloprid and Thiamethoxam Insecticides on the house fly, Musca domestica L. (Diptera: Muscidae). Egyp. Acad. J. Biol. Sci. A Entomol. 2018, 11, 33-42. [CrossRef]

119. Paleolog, J.; Wilde, J.; Siuda, M.; Bąk, B.; Wójcik, Ł.; Strachecka, A. Imidacloprid Markedly Affects Hemolymph Proteolysis, Biomarkers, DNA Global Methylation, and the Cuticle Proteolytic Layer in Western Honeybees. Apidologie 2020, 51, 620-630. [CrossRef]

120. Hu, Y.T.; Tang, C.K.; Wu, C.P.; Wu, P.C.; Yang, E.C.; Tai, C.C.; Wu, Y.L. Histone Deacetylase Inhibitor Treatment Restores Memory-Related Gene Expression and Learning Ability in Neonicotinoid-Treated Apis mellifera. Insect Mol. Biol. 2018, $27,512-521$. [CrossRef]

121. El Hassani, A.K.; Dacher, M.; Gary, V.; Lambin, M.; Gauthier, M.; Armengaud, C. Effects of Sublethal Doses of Acetamiprid and Thiamethoxam on the Behavior of the Honeybee (Apis mellifera). Arch. Environ. Contam. Toxicol. 2008, 54, 653-661. [CrossRef] [PubMed]

122. Maloney, E.M.; Liber, K.; Headley, J.V.; Peru, K.M.; Morrissey, C.A. Neonicotinoid Insecticide Mixtures: Evaluation of LaboratoryBased Toxicity Predictions Under Semi-Controlled Field Conditions. Environ. Pollut. 2018, 243, 1727-1739. [CrossRef]

123. Liang, P.; Tian, Y.A.; Biondi, A.; Desneux, N.; Gao, X.W. Short-Term and Transgenerational Effects of the Neonicotinoid Nitenpyram on Susceptibility to Insecticides in Two Whitefly Species. Ecotoxicology 2012, 21, 1889-1898. [CrossRef] [PubMed]

124. Beketov, M.A.; Liess, M. Acute and Delayed Effects of the Neonicotinoid Insecticide Thiacloprid on Seven Freshwater Arthropods. Environ. Toxicol. Chem. 2008, 27, 461-470. [CrossRef] [PubMed]

125. Kobashi, K.; Harada, T.; Adachi, Y.; Mori, M.; Ihara, M.; Hayasaka, D. Comparative Ecotoxicity of Imidacloprid and Dinotefuran to Aquatic Insects In Rice Mesocosms. EcoToxicol. Environ. Saf. 2017, 138, 122-129. [CrossRef]

126. Martínez-Paz, P.; Morales, M.; Martínez-Guitarte, J.L.; Morcillo, G. Genotoxic Effects of Environmental Endocrine Disruptors on the Aquatic Insect Chironomus riparius Evaluated Using the Comet Assay. Mut. Res. Gen. Toxicol. Environ. Mutagenesis 2013, 758, 41-47. [CrossRef]

127. Morales, M.; Martínez-Paz, P.; Martín, R.; Planelló, R.; Urien, J.; Martínez-Guitarte, J.L.; Morcillo, G. Transcriptional Changes Induced by In Vivo Exposure to Pentachlorophenol (PCP) in Chironomus riparius (Diptera) Aquatic Larvae. Aqu. Toxicol. 2014, 157, 1-9. [CrossRef] [PubMed]

128. Planelló, R.; Herrero, O.; Martínez-Guitarte, J.L.; Morcillo, G. Comparative Effects of Butyl Benzyl Phthalate (BBP) and Di (2-Ethylhexyl) Phthalate (DEHP) on the Aquatic Larvae of Chironomus riparius Based on Gene Expression Assays Related to the Endocrine System, the Stress Response and Ribosomes. Aqu. Toxicol. 2011, 105, 62-70. [CrossRef] [PubMed]

129. Park, K.; Kwak, I.S. Characterization of Heat Shock Protein 40 and 90 in Chironomus Riparius Larvae: Effects of Di (2-ethylhexyl) Phthalate Exposure on Gene Expressions and Mouthpart Deformities. Chemosphere 2008, 74, 89-95. [CrossRef] [PubMed]

130. Bovier, T.F.; Rossi, S.; Mita, D.G.; Digilio, F.A. Effects of the Synthetic Estrogen 17-A-Ethinylestradiol on Drosophila melanogaster: Dose and Gender Dependence. EcoToxicol. Environ. Saf. 2018, 162, 625-632. [CrossRef]

131. Unni, B.G.; Peck, K.E.; Pytel, M.M.; Dahm, K.H.; Bhaskaran, G.; Singh, H.R.; Kakoty, Y.; Devi, B.; Wann, S.B. Dimethyl Sulphoxide Inhibits In Vitro Synthesis of Juvenile Hormone I and II and Stimulates Juvenile Hormone III by corpora allata of Insects. Curr. Sci. 2009, 96, 1114-1119.

132. Al-Jaibachi, R.; Cuthbert, R.N.; Callaghan, A. Up and Away: Ontogenic Transference as a Pathway for Aerial Dispersal of Microplastics. Biol. Lett. 2018, 14, 20180479. [CrossRef] 
133. Akindele, E.O.; Ehlers, S.M.; Koop, J.H. Freshwater Insects of Different Feeding Guilds Ingest Microplastics in Two Gulf of Guinea Tributaries in Nigeria. Environ. Sci. Pollut. Res. 2020, 27, 33373-33379. [CrossRef]

134. Desneux, N.; Rafalimanana, H.; Kaiser, L. Dose-Response Relationship in Lethal and Behavioural Effects of Different Insecticides on the Parasitic Wasp Aphidius ervi. Chemosphere 2004, 54, 619-627. [CrossRef] [PubMed]

135. Tosi, S.; Nieh, J.C. Lethal and Sublethal Synergistic Effects of a New Systemic Pesticide, flupyradifurone (Sivanto ${ }^{\circledR}$ ), on Honeybees. Proc. R. Soc. B 2019, 286, 20190433. [CrossRef] [PubMed]

136. Haynes, K.F. Sublethal Effects of Neurotoxic Insecticides on Insect Behavior. Ann. Rev. Entomol. 1988, 33, 149-168. [CrossRef] [PubMed]

137. Colin, T.; Meikle, W.G.; Wu, X.; Barron, A.B. Traces of a Neonicotinoid Induce Precocious Foraging and Reduce Foraging Performance in Honey Bees. Environ. Sci. Technol. 2019, 53, 8252-8261. [CrossRef] [PubMed]

138. Stanley, J.; Preetha, G. Pesticide Toxicity To Arthropod Predators: Exposure, Toxicity And Risk Assessment Methodologies. In Pesticide Toxicity to Non-Target Organisms; Stanley, J., Preetha, G., Eds.; Springer: Dordrecht, The Netherlands, 2016 ; pp. 1-98.

139. Müller, T.; Römer, C.I.; Müller, C. Parental Sublethal Insecticide Exposure Prolongs Mating Response and Decreases Reproductive Output in Offspring. J. Appl. Ecol. 2019, 56, 1528-1537. [CrossRef]

140. Collotta, M.; Bertazzi, P.A.; Bollati, V. Epigenetics and Pesticides. Toxicology 2013, 307, 35-41. [CrossRef]

141. Hardstone, M.C.; Scott, J.G. Is Apis mellifera More Sensitive to Insecticides Than Other Insects? Pest Man. Sci. 2010, 66, 1171-1180. [CrossRef] [PubMed]

142. Picó, Y.; Alvarez-Ruiz, R.; Alfarhan, A.H.; El-Sheikh, M.A.; Alshahrani, H.O.; Barceló, D. Pharmaceuticals, Pesticides, Personal Care Products and Microplastics Contamination Assessment of Al-Hassa Irrigation Network (Saudi Arabia) and Its Shallow Lakes. Sci. Total Environ. 2020, 701, 135021. [CrossRef]

143. Caceres-Jensen, L.; Rodríguez-Becerra, J.; Sierra-Rosales, P.; Escudey, M.; Valdebenito, J.; Neira-Albornoz, A.; Dominguez-Vera, V.; Villagra, C.A. Electrochemical Method to Study the Environmental Behavior of Glyphosate on Volcanic Soils: Proposal of Adsorption-Desorption and Transport Mechanisms. J. Hazard. Mater. 2019, 379, 120746. [CrossRef]

144. Caceres-Jensen, L.C.; Rodríguez-Becerra, J.; Escudey, M. Impact of Physical/Chemical Properties of Volcanic Ash-Derived Soils on Mechanisms Involved During Sorption of Ionisable and Non-Ionisable Herbicides. In Advanced Sorption Process Applications; IntechOpen: Rijeka, Croatia, 2018.

145. Augustyniak, M.; Płachetka-Bożek, A.; Kafel, A.; Babczyńska, A.; Tarnawska, M.; Janiak, A.; Loba, A.; Dziewięcka, M.; KarpetaKaczmarek, J.; Zawisza-Raszka, A. Phenotypic Plasticity, Epigenetic or Genetic Modifications in Relation to the Duration of Cd-Exposure Within a Microevolution Time Range in the Beet Armyworm. PLoS ONE 2016, 11, e0167371.

146. Jadiya, P.; Nazir, A. Environmental Toxicants as Extrinsic Epigenetic Factors for Parkinsonism: Studies Employing Transgenic C. Elegans Model. CNS Neuro. Disor-Drug Targ. 2012, 11, 976-983. [CrossRef] [PubMed]

147. Colosio, C.; Rubino, F.M.; Moretto, A. Pesticides. In International Encyclopedia of Public Health, 2nd ed.; Quah, S.R., Ed.; Academic Press: New York, NY, USA, 2016; pp. 454-462.

148. Mužinić, V.; Želježić, D. Non-Target Toxicity of Novel Insecticides. Arch. Indust. Hyg. Toxicol. 2018, 69, 86-102. [CrossRef]

149. Darvas, B.; Polgar, L.A. Novel-Type Insecticides: Specificity and Effects on Non-Target Organisms. In Insecticides with Novel Modes of Action; Ishaaya, I., Horowitz, A.R., Eds.; Springer: Berlin, Germany, 1998; pp. 188-259.

150. Smith, C.J.; Perfetti, T.A. A Comparison of The Persistence, Toxicity, and Exposure to High-Volume Natural Plant-Derived and Synthetic Pesticides. Toxicol. Res. Appl. 2020, 4, 2397847320940561. [CrossRef]

151. Zahm, S.H.; Ward, M.H. Pesticides and Childhood Cancer. Environ. Health Persp. 1998, 106, 893-908.

152. Howe, C.M.; Berrill, M.; Pauli, B.D.; Helbing, C.C.; Werry, K.; Veldhoen, N. Toxicity of Glyphosate-Based Pesticides to Four North American Frog Species. Environ. Toxicol. Chem. 2004, 23, 1928-1938. [CrossRef]

153. Isenring, R. Pesticides Reduce Biodiversity. Pest. News 2010, 88, 4-7.

154. Lerro, C.C.; Freeman, L.E.; DellaValle, C.T.; Andreotti, G.; Hofmann, J.N.; Koutros, S.; Parks, C.G.; Shrestha, S.; Alavanja, M.C.; Blair, A.; et al. Pesticide Exposure and Incident Thyroid Cancer Among Male Pesticide Applicators in Agricultural Health Study. Environ. Int. 2021, 146, 106187. [CrossRef]

155. Seide, V.E.; Bernardes, R.C.; Pereira, E.J.; Lima, M.A. Glyphosate is Lethal and Cry Toxins Alter the Development of the Stingless Bee Melipona quadrifasciata. Environ. Pollut. 2018, 243, 1854-1860. [CrossRef]

156. Desneux, N.; Decourtye, A.; Delpuech, J.M. The Sublethal Effects of Pesticides on Beneficial Arthropods. Annu. Rev. Entomol. 2007, 52, 81-106. [CrossRef] [PubMed]

157. Tasei, J.N. Impact of Agrochemicals on Non-Apis Bees. In Honey Bees: Estimating the Environmental Impact of Chemicals; Taylor \& Francis Group: Abingdon, UK, 2002; pp. 101-131.

158. Hoshi, N. Adverse Effects of Pesticides on Regional Biodiversity and Their Mechanisms. In Risks and Regulation of New Technologies; Matsuda, T., Wolff, J., Tanagawa, T., Eds.; Springer: Singapore, 2021; pp. 235-247.

159. Gill, R.J.; Raine, N.E. Chronic Impairment of Bumblebee Natural Foraging Behaviour Induced by Sublethal Pesticide Exposure. Funct. Ecol. 2014, 28, 1459-1471. [CrossRef]

160. Atwood, D.; Paisley-Jones, C. Pesticides Industry Sales and Usage 2008-2012 Market Estimates; US EPA: Washington, DC, USA, 2017.

161. Caceres-Jensen, L.; Neira-Albornoz, A.; Escudey, M. Herbicides Mechanisms Involved in the Sorption Kinetic Of Ionisable And Non Ionisable Herbicides: Impact of Physical/Chemical Properties Of Soils And Experimental Conditions. In Kinetic Modeling for Environmental Systems; IntechOpen: Rijeka, Croatia, 2019. 
162. Junqueira, L.V.; Mendes, K.F.; Sousa, R.N.; Almeida, C.D.; Alonso, F.G.; Tornisielo, V.L. Sorption-Desorption Isotherms and Biodegradation of Glyphosate in Two Tropical Soils Aged with Eucalyptus Biochar. Arch. Agric. Soil Sci. 2020, 66, $1651-1667$. [CrossRef]

163. Liu, J.; Zhou, J.H.; Guo, Q.N.; Ma, L.Y.; Yang, H. Physiochemical Assessment of Environmental Behaviors of Herbicide Atrazine in Soils Associated With its Degradation and Bioavailability to Weeds. Chemosphere 2021, 262, 127830. [CrossRef]

164. Pietrzak, D.; Kania, J.; Kmiecik, E.; Malina, G.; Wator, K. Fate of Selected Neonicotinoid Insecticides in Soil-Water Systems: Current State of The Art and Knowledge Gaps. Chemosphere 2020, 255, 126981. [CrossRef]

165. Cáceres-Jensen, L.; Gan, J.; Baez, M.; Fuentes, R.; Escudey, M. Adsorption of Glyphosate on Variable-Charge, Volcanic AshDerived Soils. J. Environ. Qual. 2009, 38, 1449-1457. [CrossRef]

166. Annabi, E.; Ben Salem, I.; Abid-Essefi, S. Acetamiprid, a Neonicotinoid Insecticide, Induced Cytotoxicity and Genotoxicity in PC12 Cells. Toxicol. Mech. Methods 2019, 29, 580-586. [CrossRef]

167. Bansal, O.P. Sorption, Degradation and Movement of Three Carbamate Pesticides in Soils. Ind. J. Agric. Sci. $2011,81,578-581$.

168. Hussain, S.; Siddique, T.; Saleem, M.; Arshad, M.; Khalid, A. Impact of Pesticides on Soil Microbial Diversity, Enzymes, and Biochemical Reactions. Adv. Agric. 2009, 102, 159-200.

169. Mattina, M.J.; White, J.; Eitzer, B.; Iannucci-Berger, W. Cycling of Weathered Chlordane Residues in the Environment: Compositional and Chiral Profiles in Contiguous Soil, Vegetation, And Air Compartments. Environ. Toxicol. Chem. 2002, 21, 281-288. [CrossRef] [PubMed]

170. Folmar, L.C.; Sanders, H.O.; Julin, A.M. Toxicity of the Herbicide Glyphosate and Several of its Formulations to Fish and Aquatic Invertebrates. Arch. Environ. Contam. Toxicol. 1979, 8, 269-278. [CrossRef]

171. Aparicio, V.C.; De Gerónimo, E.; Marino, D.; Primost, J.; Carriquiriborde, P.; Costa, J.L. Environmental Fate of Glyphosate and Aminomethylphosphonic Acid in Surface Waters And Soil Of Agricultural Basins. Chemosphere 2013, 93, 1866-1873. [CrossRef]

172. Gill, J.P.; Sethi, N.; Mohan, A.; Datta, S.; Girdhar, M. Glyphosate Toxicity for Animals. Environ. Chem. Lett. 2018, 16, 401-426. [CrossRef]

173. Caceres-Jensen, L.; Rodriguez-Becerra, J.; Escudey, M.; Joo-Nagata, J.; Villagra, C.A.; Dominguez-Vera, V.; Neira-Albornoz, A.; Cornejo-Huentemilla, M. Nicosulfuron Sorption Kinetics and Sorption/Desorption on Volcanic Ash-Derived Soils: Proposal of Sorption and Transport Mechanisms. J. Hazard. Mater. 2020, 385, 121576. [CrossRef] [PubMed]

174. Murano, H.; Suzuki, K.; Kayada, S.; Saito, M.; Yuge, N.; Arishiro, T.; Watanabe, A.; Isoi, T. Influence of Humic Substances and Iron and Aluminum Ions on the Sorption of Acetamiprid to an Arable Soil. Sci. Total Environ. 2018, 615, 1478-1484. [CrossRef]

175. Fernandez-Bayo, J.D.; Nogales, R.; Romero, E. Evaluation of the Sorption Process for Imidacloprid And Diuron In Eight Agricultural Soils from Southern Europe Using Various Kinetic Models. J. Agric. Food Chem. 2008, 56, 5266-5272. [CrossRef]

176. Eggleton, P. The State of the World's Insects. Ann. Rev. Environ. Res. 2020, 26, 45. [CrossRef]

177. Studzińska, M.B.; Sallé, G.; Roczeń-Karczmarz, M.; Szczepaniak, K.; Demkowska-Kutrzepa, M.; Tomczuk, K. A Survey of Ivermectin Resistance in Parascaris Species Infected Foals in South-Eastern Poland. Act. Vet. Scand. 2020, 62, 1-5.

178. Motaung, T.E. Chloronicotinyl Insecticide Imidacloprid: Agricultural Relevance, Pitfalls and Emerging Opportunities. Crop Prot. 2020, 131, 105097. [CrossRef]

179. Saaristo, M.; Brodin, T.; Balshine, S.; Bertram, M.G.; Brooks, B.W.; Ehlman, S.M.; McCallum, E.S.; Sih, A.; Sundin, J.; Wong, B.B.; et al. Direct and Indirect Effects of Chemical Contaminants on the Behaviour, Ecology and Evolution of Wildlife. Proc. R. Soc. B Biol. Sci. 2018, 285, 20181297. [CrossRef]

180. Hallmann, C.A.; Foppen, R.P.; van Turnhout, C.A.; de Kroon, H.; Jongejans, E. Declines in Insectivorous Birds are Associated With High Neonicotinoid Concentrations. Nature 2014, 511, 341-343. [CrossRef]

181. Yusmalinar, S.; Anggtaeni, T.; Khusnan, K.; Wibowo, I.; Putra, R.E.; Ahmad, I. Reproductive Ability Enhancement of Housefly (Musca domestica Linn) (Diptera: Muscidae) Through Hormesis by Application of Sublethal Doses of Imidacloprid and Permethrin. J. Entomol. 2017, 14, 199-207. [CrossRef]

182. Chen, X.; Tang, J. Utilization of Biodiversity in Agriculture: Today and Tomorrow. Chin. J. Ecol. Agric. 2013, 21, 54-60.

183. Reilly, J.R.; Artz, D.R.; Biddinger, D.; Bobiwash, K.; Boyle, N.K.; Brittain, C.; Brokaw, J.; Campbell, J.W.; Daniels, J.; Elle, E.; et al. Crop Production in the USA is Frequently Limited by a Lack of Pollinators. Proc. R. Soc. B. Biol. Sci. 2020, $287,20200922$. [CrossRef] [PubMed]

184. Melathopoulos, A.P.; Cutler, G.C.; Tyedmers, P. Where is the Value in Valuing Pollination Ecosystem Services to Agriculture? Ecol. Econ. 2015, 109, 59-70. [CrossRef]

185. Kremen, C.; Bugg, R.L.; Nicola, N.; Smith, S.A.; Thorp, R.W.; Williams, N.M. Native Bees, Native Plants and Crop Pollination in California. Fremontia 2002, 30, 41-49.

186. Elbert, A.; Haas, M.; Springer, B.; Thielert, W.; Nauen, R. Applied Aspects of Neonicotinoid Uses in Crop Protection. Pest Man. Sci. 2008, 64, 1099-1105. [CrossRef]

187. Lu, C.; Chang, C.H.; Palmer, C.; Zhao, M.; Zhang, Q. Neonicotinoid Residues in Fruits and Vegetables: An Integrated Dietary Exposure Assessment Approach. Environ. Sci. Technol. 2018, 52, 3175-3184. [CrossRef]

188. Basley, K.; Davenport, B.; Vogiatzis, K.; Goulson, D. Effects of Chronic Exposure to Thiamethoxam on Larvae of the Hoverfly Eristalis tenax (Diptera, Syrphidae). Peer] 2018, 6, e4258. [CrossRef]

189. Georgieva, M.; Bonchev, G.; Zehirov, G.; Vasileva, V. Neonicotinoid Insecticides Exert Diverse Cytotoxic and Genotoxic Effects on Cultivated Sunflower. Environ. Sci. Pollut. G 2021, 1-15. [CrossRef] 
190. Craddock, H.A.; Huang, D.; Turner, P.C.; Quirós-Alcalá, L.; Payne-Sturges, D.C. Trends in Neonicotinoid Pesticide Residues in Food and Water in the United States, 1999-2015. Environ. Health. 2019, 18, 7. [CrossRef] [PubMed]

191. Farahat, N.M.; Zyaan, O.H.; Khaled, A.S.; Hussein, M.A. Toxic and Biochemical Effects of Imidacloprid and Tannic Acid on the Culex pipiens Larvae (Diptera: Culicidae). Int. J. Mosqu. Res. 2018, 5, 111-115.

192. Byholm, P.; Mäkeläinen, S.; Santangeli, A.; Goulson, D. First evidence of neonicotinoid residues in a long-distance migratory raptor, the European honey buzzard (Pernis apivorus). Sci. Total Environ. 2018, 639, 929-933. [CrossRef] [PubMed]

193. Piiroinen, S.; Goulson, D. Chronic Neonicotinoid Pesticide Exposure and Parasite Stress Differentially Affects Learning in Honeybees and Bumblebees. Proc. R. Soc. B Biol. Sci. 2016, 283, 20160246. [CrossRef] [PubMed]

194. Mörtl, M.; Vehovszky, Á.; Klátyik, S.; Takács, E.; Győri, J.; Székács, A. Neonicotinoids: Spreading, Translocation and Aquatic Toxicity. Int. J. Environ. Res. Public Health 2020, 17, 2006. [CrossRef] [PubMed]

195. Bordoni, L.; Gabbianelli, R. Nutrigenomics of Food Pesticides. In Principles of Nutrigenetics and Nutrigenomics; Caterina, R.D., Martinez, J.A., Kohlmeier, M., Eds.; Academic Press: Cambridge, MA, USA, 2020; pp. 513-518.

196. Parkinson, R.H.; Zhang, S.; Gray, J.R. Neonicotinoid and Sulfoximine Pesticides Differentially Impair Insect Escape Behavior and Motion Detection. Proc. Nat. Acad. Sci. USA 2020, 117, 5510-5515. [CrossRef]

197. Hoshi, N.; Hirano, T.; Omotehara, T.; Tokumoto, J.; Umemura, Y.; Mantani, Y.; Tanida, T.; Warita, K.; Tabuchi, Y.; Yokoyama, T.; et al. Insight into the Mechanism of Reproductive Dysfunction Caused by Neonicotinoid Pesticides. Biol. Pharm. Bull. 2014, 37, 1439-1443. [CrossRef]

198. Simon-Delso, N.; Amaralrogers, V.; Belzunces, L.P.; Bonmatin, J.M.; Chagnon, M.; Downs, C.; Furlan, L.; Gibbons, D.W.; Giorio, C.; Girolami, V.; et al. Systemic Insecticides (Neonicotinoids And Fipronil): Trends, Uses, Mode of Action and Metabolites. Environ. Sci. Pollut. Res. 2015, 22, 5-34. [CrossRef]

199. Millot, F.; Decors, A.; Mastain, O.; Quintaine, T.; Berny, P.; Vey, D.; Lasseur, R.; Bro, E. Field Evidence of Bird Poisonings by Imidaclo-Prid-Treated Seeds: A Review of Incidents Reported by the French SAGIR Network from 1995 to 2014 . Environ. Sci. Pollut. Res. 2017, 24, 5469-5485. [CrossRef]

200. Wang, W.; Ito, T.; Otsuka, S.; Nansai, H.; Abe, K.; Nakao, Y.; Ohgane, J.; Yoneda, M.; Sone, H. Epigenetic Effects of Insecticides on Early Differentiation of Mouse Embryonic Stem Cells. Toxicol. Vitr. 2021, 75, 105174. [CrossRef] [PubMed]

201. Arican, Y.E.; Karaman, E.F.; Özden, S. The Subcronic Effects of Acetamipride on the Global DNA Methylation Levels in Sprague-Dawley Rat Brain and Liver. Istanb. J. Pharm. 2019, 49, 167-172. [CrossRef]

202. Bradford, B.R.; Whidden, E.; Gervasio, E.D.; Checchi, P.M.; Raley-Susman, K.M. Neonicotinoid-Containing Insecticide Disruption Of Growth, Locomotion, and Fertility in Caenorhabditis elegans. PLoS ONE 2020, 15, e0238637. [CrossRef]

203. Vehovszky, Á.; Farkas, A.; Ács, A.; Stoliar, O.; Székács, A.; Mörtl, M.; Győri, J. Neonicotinoid Insecticides Inhibit Cholinergic Neuro-Transmission in a Molluscan (Lymnaea stagnalis) Nervous System. Aquat. Toxicol. 2015, 167, 172-179. [CrossRef] [PubMed]

204. Samson-Robert, O.; Labrie, G.; Chagnon, M.; Fournier, V. Planting of Neonicotinoid-Coated Corn Raises Honey Bee Mortality and Sets Back Colony DevelopmEntomol. PeerJ 2017, 5, e3670. [CrossRef]

205. Henríquez-Piskulich, P.; Schapheer, C.; Vereecken, N.; Villagra, C. Agroecological Strategies to Safeguard Insect Pollinators in Biodiversity Hotspots: Chile as a Case Study. Sustainability 2021, 13, 6728. [CrossRef]

206. Stanley, D.A.; Garratt, M.P.; Wickens, J.B.; Wickens, V.J.; Potts, S.G.; Raine, N.E. Neonicotinoid Pesticide Exposure Impairs Crop Pollination Services Provided By Bumblebees. Nature 2015, 528, 548-550. [CrossRef]

207. Li, J.; Wang, Q.; Zhang, L.; Gao, X. Characterization of Imidacloprid Resistance in the Housefly Musca domestica (Diptera: Muscidae). Pest. Biochem. Phys. 2012, 102, 109-114. [CrossRef]

208. Cutler, G.C. Insects, Insecticides and Hormesis: Evidence and Considerations for Study. Dose-Response 2013, 11, $154-177$. [CrossRef]

209. Botías, C.; David, A.; Hill, E.M.; Goulson, D. Contamination of Wild Plants Near Neonicotinoid Seed-Treated Crops, and Implications for Non-Target Insects. Sci. Total Environ. 2016, 566, 269-278. [CrossRef]

210. Forister, M.L.; Cousens, B.; Harrison, J.G.; Anderson, K.; Thorne, J.H.; Waetjen, D.; Nice, C.C.; De Parsia, M.; Hladik, M.L.; Meese, R.; et al. Increasing Neonicotinoid Use and the Declining Butterfly Fauna of Lowland California. Biol. Lett. 2016, 12, 20160475. [CrossRef] [PubMed]

211. Wilcox, A.A.; Newman, A.E.M.; Raine, N.E.; Mitchell, G.W.; Norris, D.R. Effects of Early-Life Exposure to Sublethal Levels of a Common Neonicotinoid Insecticide on the Orientation and Migration of Monarch Butterflies (Danaus plexippus). J. Exp. Biol. 2020, 224, jeb230870. [CrossRef] [PubMed]

212. Cook, N.; Green, J.; Shuker, D.M.; Whitehorn, P.R. Exposure to the Neonicotinoid Imidacloprid Disrupts Sex Allocation Cue Use During Superparasitism in the Parasitoid Wasp Nasonia vitripennis. Ecol. Entomol. 2016, 41, 693-697. [CrossRef]

213. Parra-Morales, L.B.; Alzogaray, R.; del Brio, J.; Cichón, L.; Garrido, S.A.; D’Hervé, F.; Montagna, M. Acetamiprid-Induced Response of Biotransformation and Antioxidant Parameters in the Codling Moth Cydia pomonella (Lepidoptera: Tortricidae). Int. J. Pest Manag. 2019, 67, 1-10. [CrossRef]

214. Vaiserman, A.M. Hormesis and Epigenetics: Is There a Link? Ageing Res. Rev. 2011, 10, 413-421. [CrossRef]

215. Lawrence, T.J.; Culbert, E.M.; Felsot, A.S.; Hebert, V.R.; Sheppard, W.S. Survey and Risk Assessment of Apis mellifera (Hymenoptera: Apidae) Exposure to Neonicotinoid Pesticides in Urban, Rural, and Agricultural Settings. J. Econ. Entomol. 2016, 109, 520-528. [CrossRef] 
216. Hu, Y.T.; Wu, T.C.; Yang, E.C.; Wu, P.C.; Lin, P.T.; Wu, Y.L. Regulation of Genes Related to Immune Signaling and Detoxification In Apis mellifera by an Inhibitor of Histone Deacetylation. Sci. Rep. 2017, 7, 1-4.

217. Stoughton, S.J.; Liber, K.; Culp, J.; Cessna, A. Acute and Chronic Toxicity of Imidacloprid to the Aquatic Invertebrates Chironomus Tentans and Hyalella azteca Under Constant-and Pulse-Exposure Conditions. Arch. Environ. Contam. Toxicol. 2008, $54,662-673$. [CrossRef]

218. Zhao, J.Z.; Bishop, B.A.; Grafius, E.J. Inheritance and Synergism of Resistance to Imidacloprid in the Colorado Potato Beetle (Coleoptera: Chrysomelidae). J. Econ. Entomol. 2000, 93, 1508-1514. [CrossRef]

219. Rundlöf, M.; Andersson, G.K.; Bommarco, R.; Fries, I.; Hederström, V.; Herbertsson, L.; Jonsson, O.; Klatt, B.K.; Pedersen, T.R.; Yourstone, J.; et al. Seed Coating With a Neonicotinoid Insecticide Negatively Affects Wild Bees. Nature 2015, 521, 77-80. [CrossRef]

220. Peng, Y.C.; Yang, E.C. Sublethal Dosage of Imidacloprid Reduces the Microglomerular Density of Honey Bee Mushroom Bodies. Sci. Rep. 2016, 6, 19298. [CrossRef]

221. Di Prisco, G.; Cavaliere, V.; Annoscia, D.; Varricchio, P.; Caprio, E.; Nazzi, F.; Gargiulo, G.; Pennacchio, F. Neonicotinoid Clothianidin Adversely Affects Insect Immunity and Promotes Replication of a Viral Pathogen in Honey Bees. Proc. Nat. Acad. Sci. USA 2013, 110, 18466-18471. [CrossRef] [PubMed]

222. Biergans, S.D.; Claudianos, C.; Reinhard, J.; Galizia, C.G. DNA Methylation Mediates Neural Processing After Odor Learning in the Honeybee. Sci. Rep. 2017, 7, 43635. [CrossRef] [PubMed]

223. Chaudhary, O.P.; Poonia, R. Qualitative Decline of Pollinator Spectrum in Sunflower Agro Ecosystem. Ind. J. Ecol. 2018, 45, 592-597.

224. Eisenhauer, N.; Bonn, A.; Guerra, C.A. Recognizing the Quiet Extinction of Invertebrates. Nat. Commun. 2019, 10, 1-3. [CrossRef]

225. Rockström, J.; Steffen, W.; Noone, K.; Persson, Å.; Chapin, F.S., III; Lambin, E.; Lenton, T.M.; Scheffer, M.; Folke, C.; Schellnhuber, H.J.; et al. Planetary Boundaries: Exploring the Safe Operating Space for Humanity. Ecol. Soc. 2009, 14, 32. [CrossRef]

226. Summerhayes, C.P.; Zalasiewicz, J. Global Warming and the Anthropocene. Geol. Today 2018, 34, 194-200. [CrossRef]

227. Hobbie, S.E.; Grimm, N.B. Nature-Based Approaches to Managing Climate Change Impacts in Cities. Phil. Tran. R. Soc. B 2020, 375, 20190124. [CrossRef]

228. Nolan, R.H.; Boer, M.M.; Collins, L.; Resco de Dios, V.; Clarke, H.; Jenkins, M.; Kenny, B.; Bradstock, R.A. Causes and Consequences of Eastern Australia's 2019-20 Season of Mega-Fires. Glob. Chang. Biol. 2020, 26, 1039-1041. [CrossRef]

229. Edie, S.M.; Huang, S.; Collins, K.S.; Roy, K.; Jablonski, D. Loss of Biodiversity Dimensions Through Shifting Climates and Ancient Mass Extinctions. Integ. Comp. Biol. 2018, 58, 1179-1190. [CrossRef]

230. Abraham, J.P.; Baringer, M.; Bindoff, N.L.; Boyer, T.; Cheng, L.J.; Church, J.A.; Conroy, J.L.; Domingues, C.M.; Fasullo, J.T.; Gilson, J.; et al. A Review of Global Ocean Temperature Observations: Implications for Ocean Heat Content Estimates and Climate Change. Rev. Geophys. 2013, 51, 450-483. [CrossRef]

231. Cáceres, L.; Fuentes, R.; Escudey, M.; Fuentes, E.; Báez, M.E. Metsulfuron-Methyl Sorption/Desorption Behavior on Volcanic Ash-Derived Soils. Effect of Phosphate And Ph. J. Agric. Food Chem. 2010, 58, 6864-6869. [CrossRef] [PubMed]

232. Mantyka-pringle, C.S.; Martin, T.G.; Rhodes, J.R. Interactions Between Climate and Habitat Loss Effects on Biodiversity: A Systematic Review and Meta-Analysis. Glob. Chang. Biol. 2012, 18, 1239-1252. [CrossRef]

233. Singh, J.S. The Biodiversity Crisis: A Multifaceted Review. Curr. Sci. 2002, 82, 638-647.

234. Luiza-Andrade, A.; Brasil, L.S.; Benone, N.L.; Shimano, Y.; Farias, A.P.; Montag, L.F.; Dolédec, S.; Juen, L. Influence of Oil Palm Monoculture on the Taxonomic and Functional Composition of Aquatic Insect Communities in Eastern Brazilian Amazonia. Ecol. Indic. 2017, 82, 478-483. [CrossRef]

235. Guenat, S.; Kunin, W.E.; Dougill, A.J.; Dallimer, M. Effects of Urbanisation and Management Practices on Pollinators in Tropical Africa. J. Appl. Ecol. 2019, 56, 214-224. [CrossRef]

236. Elmqvist, T.; Zipperer, W.; Güneralp, B. Urbanization, Habitat Loss, Biodiversity Decline: Solution Pathways to Break the Cycle. In Routledge Handbook of Urbanization and Global Environmental Change; Seta, K., Solecki, W.D., Griffith, C.A., Eds.; Routledge: London, UK, 2016.

237. Marcantonio, M.; Rocchini, D.; Geri, F.; Bacaro, G.; Amici, V. Biodiversity, Roads, \& Landscape Fragmentation: Two Mediterranean Cases. Appl. Geogr. 2013, 42, 63-72.

238. Goosem, M. Fragmentation Impacts Caused by Roads Through Rainforests. Curr. Sci. 2007, 93, 1587-1595.

239. Geneletti, D. Biodiversity Impact Assessment of Roads: An Approach Based on Ecosystem Rarity. Environ. Impact Assess. Rev. 2003, 23, 343-365. [CrossRef]

240. Butt, N.; Beyer, H.L.; Bennett, J.R.; Biggs, D.; Maggini, R.; Mills, M.; Renwick, A.R.; Seabrook, L.M.; Possingham, H.P. Biodiversity Risks From Fossil Fuel Extraction. Science 2013, 342, 425-426. [CrossRef]

241. Virah-Sawmy, M.; Ebeling, J.; Taplin, R. Mining and Biodiversity Offsets: A Transparent and Science-Based Approach to Measure “No-Net-Loss". J. Environ. Manag. 2014, 143, 61-70. [CrossRef]

242. Maiti, S.K.; Chowdhury, A. Effects of Anthropogenic Pollution on Mangrove Biodiversity: A Review. J. Environ. Prot. 2013, 4, 1428-1434. [CrossRef]

243. McNeely, J.A. The Sinking Ark: Pollution and the Worldwide Loss of Biodiversity. Biodivers. Conserv. 1992, 1, 2-18. [CrossRef]

244. Baur, B.; Cremene, C.; Groza, G.; Rakosy, L.; Schileyko, A.A.; Baur, A.; Stoll, P.; Erhardt, A. Effects of Abandonment of Subalpine Hay Meadows on plant and Invertebrate Diversity in Transylvania, Romania. Biol. Conserv. 2006, 132, 261-273. [CrossRef] 
245. MacDonald, D.; Crabtree, J.R.; Wiesinger, G.; Dax, T.; Stamou, N.; Fleury, P.; Lazpita, J.G.; Gibon, A. Agricultural Abandonment in Mountain Areas of Europe: Environmental Consequences and Policy Response. J. Environ. Man. 2000, 59, 47-69. [CrossRef]

246. Cristi de Barros, E.C.; Ventura, H.V.; Gontijo, P.C.; Pereira, R.R.; Picanço, M.C. Ecotoxicological Study of Insecticide Effects on Arthropods in Common Bean. J. Insect Sci. 2015, 15, 1. [CrossRef]

247. Liu, S.; Jaouannet, M.; Dempsey, D.M.; Imani, J.; Coustau, C.; Kogel, K.H. RNA-Based Technologies for Insect Control in Plant Production. Biotech. Adv. 2020, 39, 107463. [CrossRef] [PubMed]

248. Rada, S.; Schweiger, O.; Harpke, A.; Kühn, E.; Kuras, T.; Settele, J.; Musche, M. Protected Areas do not Mitigate Biodiversity Declines: A Case Study on Butterflies. Div. Distr. 2019, 25, 217-224. [CrossRef]

249. Rostant, W.G.; Wedell, N.; Hosken, D.J. Transposable Elements and Insecticide Resistance. Adv. Gen. 2012, 78, $169-201$.

250. Gutzat, R.; Scheid, O.M. Epigenetic responses to stress: Triple defense? Curr. Opin. Plant Biol. 2012, 15, 568-573. [CrossRef]

251. Woodcock, B.A.; Bullock, J.M.; Shore, R.F.; Heard, M.S.; Pereira, M.G.; Redhead, J.; Ridding, L.; Dean, H.; Sleep, D.; Henrys, P.; et al. Country-Specific Effects of Neonicotinoid Pesticides on Honey Bees and Wild Bees. Science 2017, 356, 1393-1395. [CrossRef]

252. Barbieri, R.F.; Lester, P.J.; Miller, A.S.; Ryan, K.G. A Neurotoxic Pesticide Changes the Outcome of Aggressive Interactions Between Native and Invasive Ants. Proc. R. Soc. B Biol. Sci. 2013, 280, 20132157. [CrossRef]

253. Barbosa, W.F.; Smagghe, G.; Guedes, R.N. Pesticides and Reduced-R isk Insecticides, Native Bees and Pantropical Stingless Bees: Pitfalls and Perspectives. Pest Man. Sci. 2015, 71, 1049-1053. [CrossRef] [PubMed]

254. Skinner, M.K.; Ben Maamar, M.; Sadler-Riggleman, I.; Beck, D.; Nilsson, E.; McBirney, M.; Klukovich, R.; Xie, Y.; Tang, C.; Yan, W. Alterations in Sperm DNA Methylation, Non-Coding RNA and Histone Retention Associate With DDT-Induced Epigenetic Transgenerational Inheritance of Disease. Epig. Chrom. 2018, 11, 1-24. [CrossRef]

255. Vargas, A.O.; Botelho, J.F.; Mpodozis, J. The Evolutionary Consequences of Epigenesis and Neutral Change: A Conceptual Approach at the Organismal Level. J. Exp. Zool. Part B Mol. Dev. Evol. 2020. [CrossRef]

256. Stavert, J.R.; Pattemore, D.E.; Gaskett, A.C.; Beggs, J.R.; Bartomeus, I. Exotic Species Enhance Response Diversity to Land-Use Change But Modify Functional Composition. Proc. R. Soc. B Biol. Sci. 2017, 284, 20170788. [CrossRef] [PubMed]

257. Wilting, H.C.; Schipper, A.M.; Bakkenes, M.; Meijer, J.R.; Huijbregts, M.A. Quantifying Biodiversity Losses Due to Human Consumption: A Global-Scale Footprint Analysis. Environ. Sci. Technol. 2017, 51, 3298-3306.

258. Biesmeijer, J.C.; Roberts, S.P.; Reemer, M.; Ohlemüller, R.; Edwards, M.; Peeters, T.; Schaffers, A.P.; Potts, S.G.; Kleukers, R.J.; Thomas, C.D.; et al. Parallel Declines in Pollinators and Insect-Pollinated Plants in Britain and The Netherlands. Science 2006, 313, 351-354. [CrossRef]

259. Steffan-Dewenter, I.; Potts, S.; Packer, L. Pollinator Diversity and Crop Pollination Services are at Risk. Trends Ecol. Evol. 2005, 20, 651-652. [CrossRef] [PubMed]

260. Pettis, J.S.; Lichtenberg, E.M.; Andree, M.; Stitzinger, J.; Rose, R. Crop Pollination Exposes Honey Bees to Pesticides Which Alters Their Susceptibility to the Gut Pathogen Nosema ceranae. PLoS ONE 2013, 8, e70182.

261. Pievani, T. The Sixth Mass Extinction: Anthropocene and the Human Impact on Biodiversity. Rend. Lincei 2014, $25,85-93$. [CrossRef]

262. Schapheer, C.; Pellens, R.; Scherson, R. Arthropod-Microbiota Integration: Its Importance for Ecosystem Conservation. Front. Microbiol. 2021, 12, 1-18. [CrossRef] 